\begin{tabular}{|c|c|c|c|}
\hline Article Info & RESEARCH ARTICLE & ARAŞTIRMA MAKALESİ & \\
\hline Title of Article & \multicolumn{2}{|c|}{$\begin{array}{c}\text { Materials and Production Techniques in } \\
\text { Environmental Approaches; Contemporary } \\
\text { Adobe Buildings }\end{array}$} & \\
\hline $\begin{array}{l}\text { Corresponding } \\
\text { Author }\end{array}$ & \multicolumn{2}{|c|}{$\begin{array}{l}\text { Seyhan YARDIMLI } \\
\text { İstanbul Okan Üniversitesi Sanat Tasarım ve Mimarlık Fakültesi, Mimarlık Bölümü, } \\
\text { seyhanyardimli@ gmail.com, seyhan.yardimli@ okan.edu.tr }\end{array}$} & \\
\hline $\begin{array}{l}\text { Received Date } \\
\text { Accepted Date }\end{array}$ & \multicolumn{2}{|l|}{$\begin{array}{l}23.03 .2021 \\
12.06 .2021\end{array}$} & \\
\hline DOI Number & \multicolumn{2}{|l|}{ https://doi.org/10.35674/kent.901861 } & \\
\hline Author / Authors & Seyhan YARDIMLI & ORCID: 0000-0001-7186-9000 & \\
\hline How to Cite & \multicolumn{2}{|c|}{$\begin{array}{l}\text { YARDIMLI, S. (2021). Cevreci Yaklaşımlarda Malzeme ve Yapım Tekniği; } \\
\text { Çağdaş Kerpiç Yapılar, Kent Akademisi, Volume, 14, Issue 2, 389-413, }\end{array}$} & $\begin{array}{l}\text { Kent Akademisi } \\
\text { Urban Academy }\end{array}$ \\
\hline
\end{tabular}

\title{
Çevreci Yaklaşımlarda Malzeme ve Yapım Tekniği; Çağdaş Kerpiç Yapılar
}

\section{ABSTRACT:}

Today, increasing environmental pollution and ecological problems reveal that people should be more sensitive to their environment. The building sector is also one of the important sectors that increase environmental pollution. For this reason, important studies have been initiated in terms of environmentally friendly construction materials and projects. At the same time, the energy requirement during the use of a building constitutes a significant amount of consumption, so it is also important to search for construction systems and materials that will provide more comfortable living conditions with less energy. In this direction, many studies are carried out all over the world. These studies are investigated both in order to eliminate the materials that cause waste to the environment and to use more environmentally friendly materials. In this study, first of all, important examples containing construction techniques and materials developed within the framework of these environmental approaches are given. Secondly, in addition to all these environmentalist studies, mudbrick structures, which are a traditional system product, have been developed with some additives and application techniques, and modern building examples and construction techniques applied today are included, and the subject is conveyed with applied examples. In the study carried out with a literature study, both examples made within the framework of environmentalist approaches and contemporary adobe buildings were discussed and these building types were evaluated in terms of environmentalist approaches. All of these examples are examples that produce very environmentally friendly solutions according to the place and purpose they are made. Of course, material researches and construction techniques carried out with environmentally friendly approaches in the world are very important and these studies will continue. However, in the study, it was found that the adobe buildings

${ }^{1}$ Istanbul Okan University, Faculty of Art, Design and Architecture, seyhanyardimli@gmail.com 
produced with the modern system are very environmentally friendly structures compared to other environmentally friendly structures.

KEYWORDS: Contemporary adobe building, Adobe construction technique, Adobe building, Recycling, Environmentalist approaches in architecture

\section{ÖZ:}

Günümüzde artan çevre kirliliği ve ekolojik sorunlar insanların çevrelerine karşı daha duyarlı olmaları gerektiğini ortaya koymaktadır. Yapı sektörü de çevre kirliliğini arttıran önemli sektörlerden biridir. Bu nedenle kullanılan yapı malzemelerinin ve projelerin çevreci olmaları açısından önemli çalışmalar başlatılmıştır. Aynı zamanda bir yapının kullanımı sürecindeki enerji gereksinimi de önemli bir tüketim miktarı oluşturmakta dolayısı ile daha az enerji ile daha konforlu yaşama koşullarını sağlayacak yapım sistemleri ve malzemelerinin araştırılması da önem kazanmaktadır. Bu doğrultuda tüm dünyada pek çok çalışma yapılmaktadır. Bu çalışmalar hem çevreye atık oluşturan malzemelerin ortadan kaldırılması amacıyla hem de daha çevreci malzemelerin kullanılması açısından araştırılmaktadır. $\mathrm{Bu}$ çalışmada öncelikle bu çevreci yaklaşımlar çerçevesinde geliştirilen yapım teknik ve malzemelerini içeren önemli örneklere yer verilmiştir. İkinci olarak ise tüm bu çevreci araştırmalar yanında bir geleneksel sistem ürünü olan kerpiç yapıların bazı katkı ve uygulama teknikleri ile geliştirilerek günümüzde uygulanmış modern yapı örneklerine ve yapım tekniklerine değinilmiş, konu uygulanmış örneklerle aktarılmıştır. Literatür çalışması ile yürütülen çalışmada hem çevreci yaklaşımlar çerçevesinde yapılan örnekler hem çağdaş kerpiç yapılar ele alınmış ve çevreci yaklaşımlar açısından bu yapı türleri değerlendirilmiştir. Bu örneklerin hepsi yapıldıkları yer ve amaca göre oldukça çevreci çözümler üreten örneklerdir. Dünyada çevreci yaklaşımlarla yapılan malzeme araştırmaları ve yapım teknikleri elbette çok önemlidir ve bu çalışmalar sürdürülecektir. Ancak yapılan çalışmada çağdaş sistemle üretilen kerpiç yapıların diğer çevreci yapılara göre de oldukça çevreci yapılar oldukları bulgusu ortaya konulmuştur.

ANAHTAR KELIMELER: Çağdaş kerpiç yapı, Kerpiç yapım tekniği, Kerpiç yapı, Geri dönüşüm, Mimarlıkta çevreci yaklaşımlar

\section{“Çevreci Yaklaşımlarda Malzeme ve Yapım Tekniği; Çağdaş Kerpiç Yapılar”}

\section{GíRIŞ:}

Günümüzde yaşanan çevre kirliliği, aşırı tüketilen doğal kaynaklar, ekosistemin bozulması, doğal afetlerin ve bazı bölgelerde kuraklığın artması (Arslan, 2014), enerji üretim ve kullanımının getirdiği sorunlar tüm yaşama koşullarının çevreci olma gerekliliğini her gün yeniden hatırlatmaktadır. İnşaat sektörü de bu kirliliğin önemli bir parçasını oluşturmaktadır. Hem inşaatın yapım aşamasında kullanılan malzemelerin üretimi, taşınması gibi süreçlere bağlı olarak enerji tüketimi ve doğaya salınan zararlı gazlar, hem yapım sonrasında binaların iklimlendirilmesi, aydınlatılması vb. için kullanılan enerji doğal kaynakları tüketmekte ve çevre kirliliğine neden olmaktadır.

İnşaat sektöründe kullanılan malzeme doğal kaynakların \%30’unu, enerji kaynaklarının \%40’ını oluşturmaktadır. Aynı zamanda küresel ısınma nedeni olan $\mathrm{CO}_{2}$ salınımının \%35'ini de yine inşaat sektörü oluşturmaktadır (Çekirge ve Çubukçuoğlu, 2017). Buna karşın küresel sera gazı salınımının (GHG) (global greenhouse gas) en kolay azaltılabileceği sektör de yine inşaat sektörü olarak belirtilmiştir (URL 1). Bu bağlamda çevreyi koruma amacıyla pek çok sertifika sistemi geliştirilmekte ve bu süreç için de bazı standartlar oluşturulmaya çalışılmaktadır. Karbon sıfır bina üretmek, karbon ayak izi, akıllı bina, ekolojik, enerji korunumlu, çevreci vb. bina yaklaşımları gibi çalışmalar her geçen gün önem kazanmakta ve yaygınlaşmaktadır (Utkutuğ, 2011).

Bu çevreci yaklaşımlar insanları geri dönüşüm konusunda da araştırmalara yöneltmektedir. Dünya'da ortalama her yıl iki milyar tonun üzerinde atık ortaya çıkmaktadır. Bu nedenlerle atıkların yeniden kullanımı için çalışmalar yapılmaktadır. Bu çalışmaların bir bölümünde de atıkların inşaat malzemesi olarak kullanım olanakları araştırılmaktadır. Bu amaçla araba lastiği, pet şişeler, karton bardaklar, ahşap palet ve taşıma kolileri, kağıt gibi malzemelerin inşaat malzemesi olarak kullanılmasına çalışılmaktadır (Tandoğan, 2018). Elbette inşaat atıkları da geri dönüşümlü malzemeler arasında önemli bir yer tutmaktadır. Bir inşaatın yıkılmasından sonra ortaya çıkan atıklar da geri dönüştürülerek kullanılabilmektedir. Aynı zamanda yapıların kullanım süreçlerinde gereken enerjinin de 
minimumda tutulması enerji tüketimi açısından oldukça önemlidir. Tüm bu faktörler göz önüne alındığında aslında yapıların hem atık oluşturmayan malzemelerle yapılması hem az enerji ile iklimlendirilmesi en uygun çözümü getirmektedir.

Tüm bu açılardan bakıldığında kerpiç yapılar pek çok açıdan istenen koşulları sağlamaktadır denilebilir. Günümüzde modern yapım teknikleri kullanılarak kerpiç yapılar çok daha kısa sürelerde ve görsel olarak da çok sıcak ve beğenilen bir malzeme olarak yeniden gündeme gelmiştir. Çağdaş yapım teknikleri kullanılarak yekpare ve düzgün duvar yüzeyleri oluşturulabilmekte, bazı katkılar da kullanılarak bu yapıların suya karşı dayanımları daha fazla arttırılabilmektedir. Bu çalışmada hem atıkların kullanımı ile ilgili mimari çözüm araştırmalarına hem çağdaş kerpiç yapılara yer verilmiş̧tir. Yapı sektöründe kerpiç yapıların yeniden değerlendirilmesi gerektiğine vurgu yapılması çevre koruma yaklaşımları açısından bakıldığında oldukça önemlidir. Çalışmada çevreci çözümler üretmek amacıyla yapılmış yapılara ve çağdaş kerpiç yapıların çevre kirliliği açısıından bakıldığında ne kadar önemli çözümler getirdiğine vurgu yapılmak istenilmiştir.

\section{Mimaride Çevreci Yaklaşımlar, Malzeme ve Yapım Tekniği Araştırmaları}

Çevresel sorunlara çözüm üretmek, daha az tüketmek, daha ekonomik çözümler bulmak gibi amaçlarla atıkların değerlendirilmesi, bölgesel malzemelerle çözümler üretilmesi, az gelişmiş bölgelerin ihtiyaçları için daha ekonomik çözümlerin geliştirilmesi çalışmaları her geçen gün daha önemli hale gelmiştir. Bu amaçla pek çok mimar ve şirket özgün, farklı ve bölgesel çözümler üretme çabasındadır. Bu bölümde bu çalışmaların birkaçına yer verilmiştir.

\section{Mokoko Yüzen Okulu}

Mokoko yüzen okulu hem ekonomik ve çevreci bir çözüm üretmek hem gelgit olayı ile farklı su seviyelerinin getirdiği sorunlara çözüm bulmak amacıyla geliştirilen projelerden biridir. Okul, Afrika Nijerya'nın ikinci en kalabalık şehri Laogos'ta suda yüzen şekilde geliştirilmiş bir yapıdır. Coğrafyanın düzgün ıslah edilmemiş arazisi ve oluşan seller, riskli bir yapı zemini oluşturmaktadır. Buna çözüm olarak yüzen bir yapı tekniği düşünülmüştür ve projede 16 boş plastik varil birbirlerine bağlanarak yüzen bir zemin oluşturulmuştur. Yapının strüktürü bu zemin üzerinde inşaa edilmiştir (Şekil $1 \mathrm{a}, \mathrm{b}, \mathrm{c}$ ).

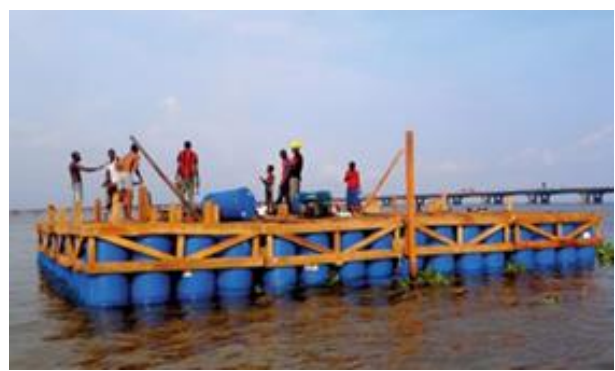

Şekil 1 a. Yapının zeminini oluşturan platform (URL 2)

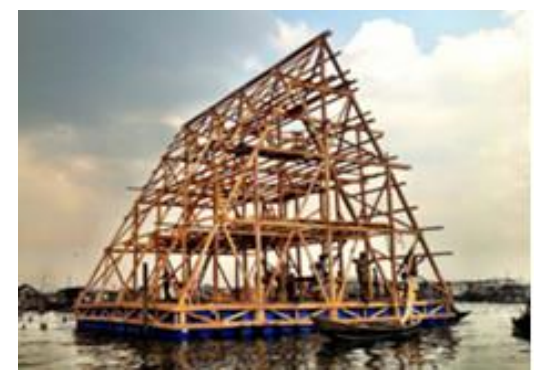

b. Yüzen okul yapısının iskeleti (Bilgiç, 2016)

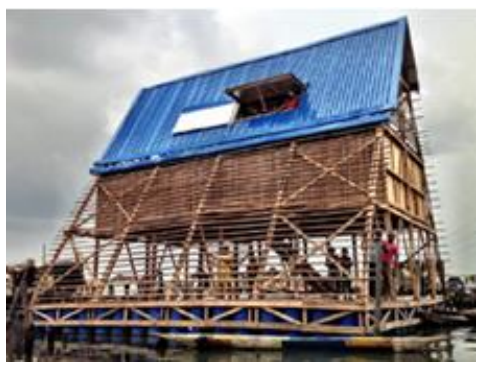

c. Mokoko yüzen okulu görünüşü (Ayc1, 2021)

Bu projenin aynı zamanda başka yapı türlerine de adapte edilerek kullanılması da amaçlanmıştır. Bina bölgesel bir kereste fabrikasından temin edilen ahşaplar ve yakın çevreden getirilen bambular ile yenilikçi bir strüktür anlayışıyla yapılmıştır (Bilgiç, 2016; Ayc1, 2021).

\section{Anupama Kundoo - Yapıda Su Künkleri Kullanımı}

Hindistan'lı Mimar Anupama Kundoo da yakın çevreden elde edilebilen atık veya ekonomik malzemelerle farklı tasarımlar geliştirmektedir. Örneğin topraktan üretilen su künkleri ile bir yapı tasarlamıştır. Bu malzeme ucuz ve kolay elde edilebilmesi ve çevreci bir malzeme olması nedeniyle tercih edilmiştir. Topraktan elde edilen künkler su borusu oluşturacak şekilde birbirine geçmek üzere açılı yapılmışlardır. Tasarımda bu künkler yapı örtüsü amacıyla bir taşıyıcı strüktür üzerine yerleştirilmiş ve inşaat malzemesi olarak kullanılmışlardır (Şekil $2 \mathrm{a}, \mathrm{b}$ ). 


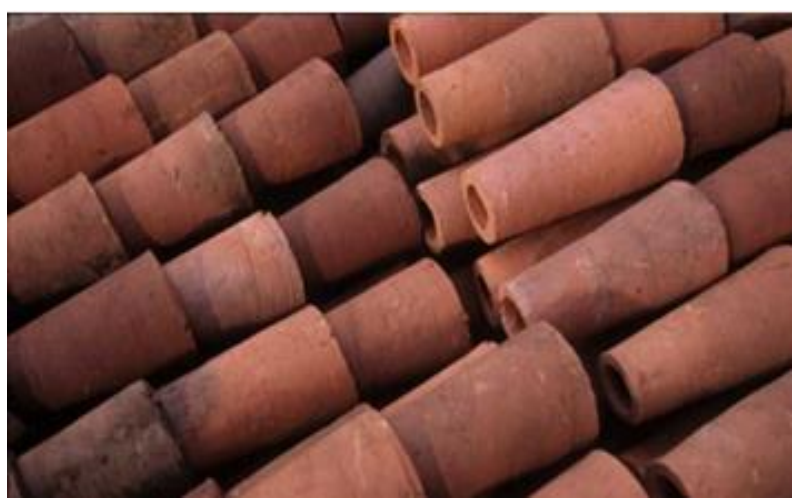

Şekil 2 a. Yapıda kullanılan su künkleri

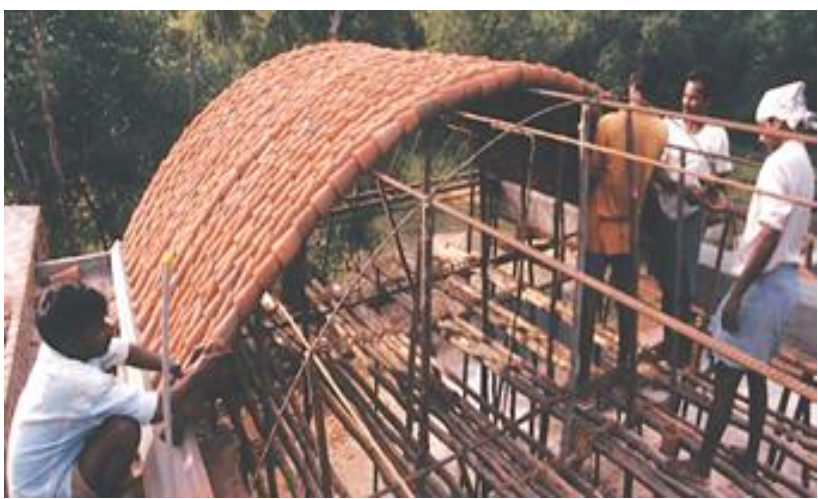

b. Künklerden yapı örtüsü oluşturma (Kundoo, 2017)

\section{Anupama Kundoo - Yapıda Cam Bardak Kullanımı}

Yine farklı atık malzemelerin değerlendirilmesi amacıyla Anupama Kundoo tarafindan cam bardaklar beton harç bağlayıcı kullanılarak farklı formda bir yapı tasarımında kullanılmışlardır (Şekil 3 a, b).

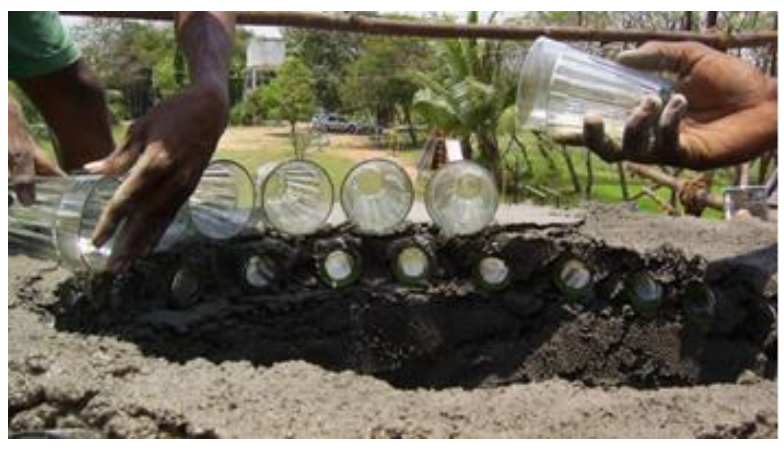

Şekil 3 a. Cam bardakların yapıda kullanımı

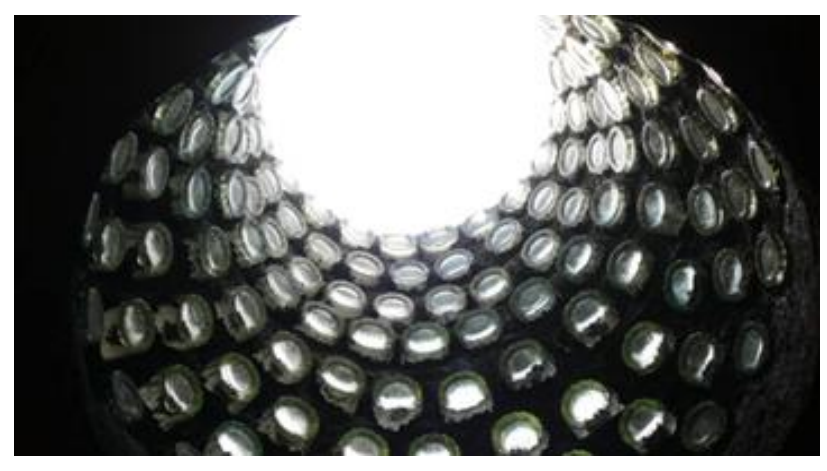

b. Yapı içinden görünüş (Kundoo, 2017)

\section{Dönüştürülmüş İnşaat Atıkları Kullanımı}

İnşaat atıkları da çevre kirletici olarak önemli bir sorun oluşturmaktadır. Bu atıkların kullanılması amacıyla pek çok çalışma yapılmaktadır. Bunlardan birisi de yıkılan binaların metal bölümleri ayrıldıktan sonra kalan atıkların değerlendirilme çalışmasıdır. Bu çalışmada bina atıklarının metal bölümleri dışında kalanlar mikserlerden geçirilerek toz haline getirilmekte ve bu tozlar da yeniden bağlayıcı ile karıştırılarak istenen boy ve renkte tuğla veya kaplama malzemesi olarak üretilmektedirler. Böylelikle 100 000'lerce kg'lık atık inşaat malzemesi yeniden kullanılabilir hale getirilebilmektedir (Şekil 4 a, b) (URL 3). 


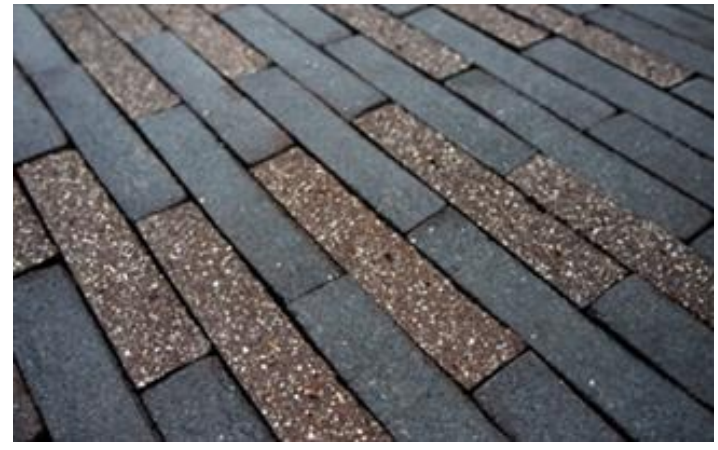

Şekil 4 a. Atık inşaat malzemelerinden geri dönüşüm ile elde edilen zemin kaplama malzemesi

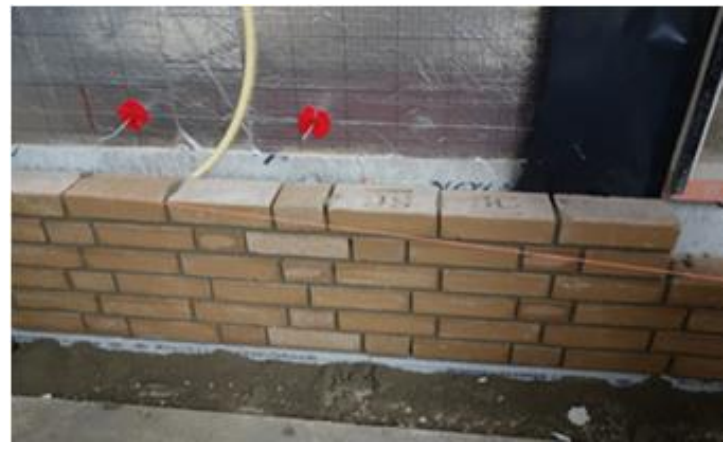

b. Tuğla örnekleri (URL 3)

\section{Atık Pet Șișe Kullanımı}

Atıkların kullanımı için geliştirilmiş bir başka proje pet şişe kullanımı ile ilgili olarak tasarlanmıştır. Hollanda Ensche'de Pet pavyonu 6X30 metrelik geçici bir yapı olarak inşaa edilmiştir. Bu yapıda ana taşıyıcı olarak çelik kullanılmıştır. Duvarlar için oluklu şeffaf levhalar oluşturulmuş ve bunların bir bölümü pet şişelerle doldurulmuştur (Şekil $5 \mathrm{a}, \mathrm{b}$ ). Pet şişeler yakılmak üzere toplanmış firınlardan temin edilerek kullanılmıştır (URL 4).

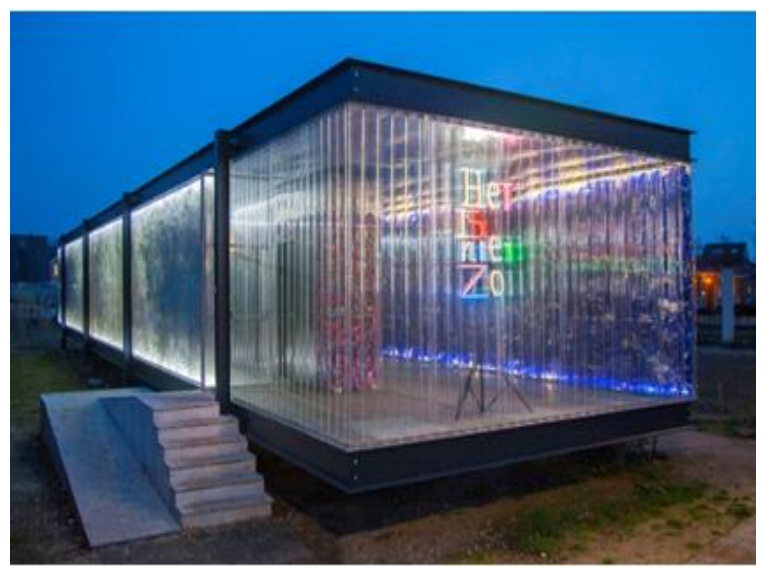

Şekil 5 a. Duvarlarında pet şişe kullanılmış Pavyon (URL 4)

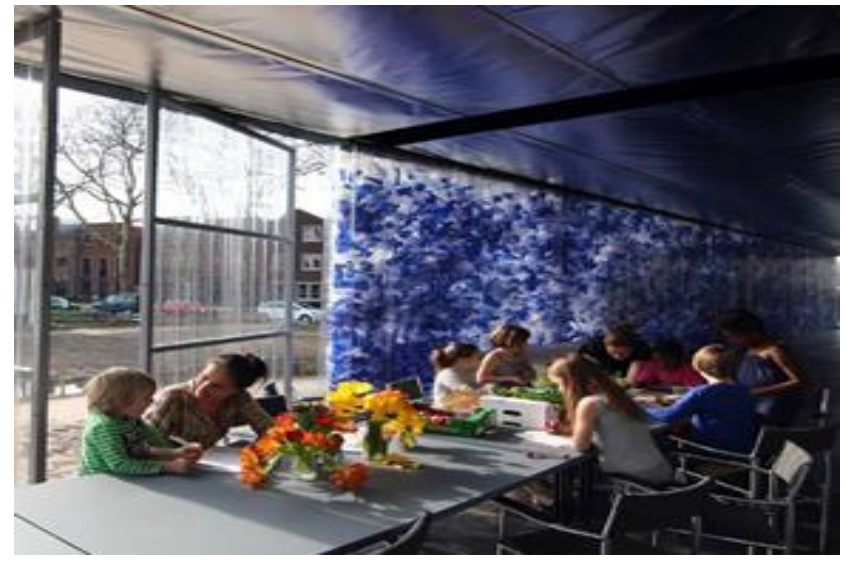

b. İçerden görünüş (URL 4)

\section{Atık Araba Lastiği Kullanımı}

Çevreyi kirleten pek çok atık malzemeden biri de araba lastikleridir. Bu lastiklerin de çeşitli şekillerde kullanımı hakkında çalışmalar yapılmaktadır. Bu çalışmalardan birisi Earthship olarak adlandırılan projedir. Taos'taki Reynolds Eartship Biotecture'un kurucusu Mimar Michael Reynolds'a göre tasarlanan bu yapılar çevreyi kirletmeyen, yenilenebilir enerji kaynakları ile ısıtma, soğutma ve güç ihtiyaçlarını karşılamak için akıllı tasarımdan yararlanan sürdürülebilir evlerdir. Bu çevreci tasarımda geri dönüşüm malzemeleri (aliminyum konserve kutuları, plastik şişeler, karton) kullanılmıştır. Eski lastiklerin içi toprak doldurularak duvarlar yapılmıştır. Oluşturulan yapı kabuğu ile 1sı korunumu sağlanmaktadır. Güneş 1şı̆̆ı iç mekanı daha fazla aydınlatacak şekilde planlanmıştır. Elektrik, güneş panelleri tarafından üretilmekte ve pillerde biriktirilmektedir. Yağmur ve kar suyu biriktirilerek kullanılmakta ve aynı zamanda kullanılmış sular da tuvalet sifonu ve bitki sulama için gri su olarak değerlendirilmektedir. Bu yapıların belediye hizmetlerinden yararlanmadan kullanılabilmesi amaçlanmıştır (Şekil 6) (URL 5). 


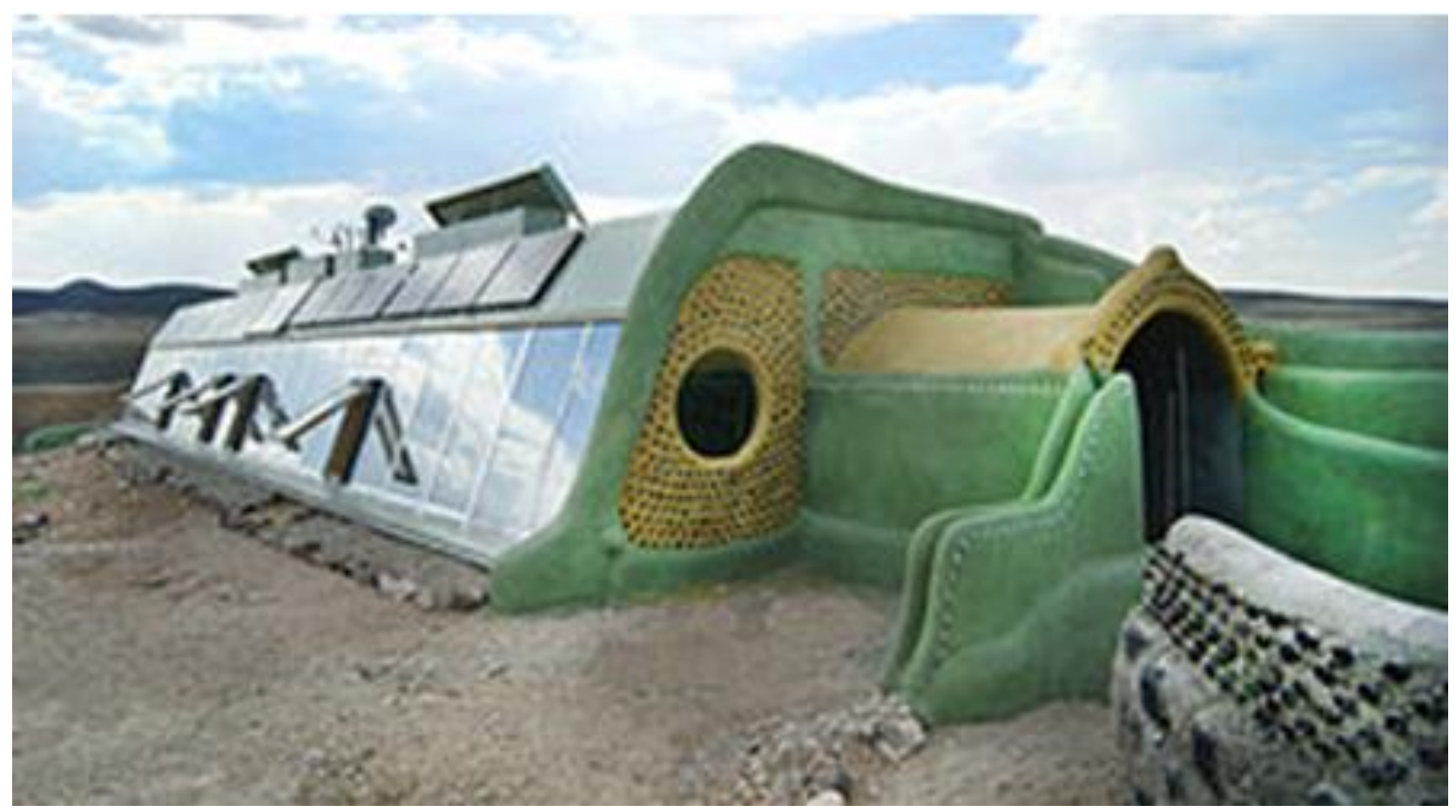

Şekil 6. Earthsip- Taos, New Mexico (URL 5)

\section{Kağıttan Elde Edilen Tüplerin Kullanımı}

Kağıt malzemenin sıkıştırılıp tüp haline getirilerek kullanımı ile ilgili bir örnek yapı ise Shigeru Ban tarafından geliştirilmiş̧ir. Shigeru Ban, özellikle afet bölgelerinde kullanılmak üzere kağıt esaslı karton tüplerle yaptığı binalar ile 2014 Pritzker Mimarlık Ödülü'nün 37. sini almış ünlü Japon mimardır (URL 6). Karton tüpler iç ve dıştan poliüretan kaplama ile su geçirmez hale getirilmiştir. Yüksek bir yoğunluğa sahip olması nedeniyle bu karton tüplerin yanması da oldukça zordur. Ban, karton tüplerin yanı sıra bambu ve ahşap ta kullanmıştır. Kullandığı malzemeler geri dönüştürülebilir malzemelerdir. Sydney Sherman Çağdaş Sanat Vakfı Bahçesindeki Shigeru Ban'ın yaptığı geçici afet barınakları Şekil 7 a, b, c'de görülmektedir.

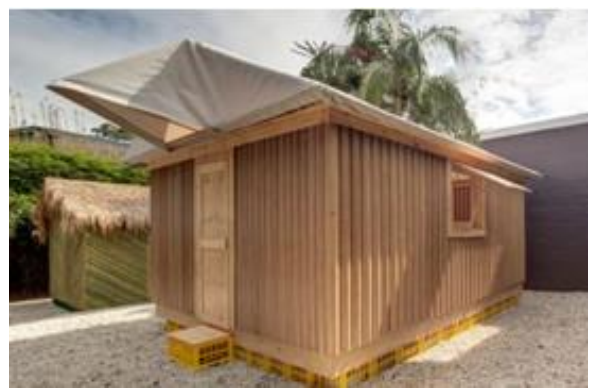

Şekil 7 a. Karton tüp kullanılmış geçici afet barınağ 1

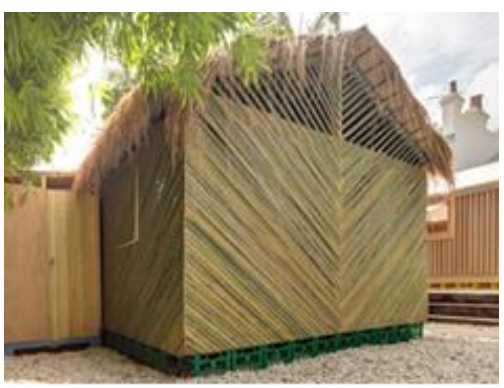

b. Bambu kullanılmış örnek

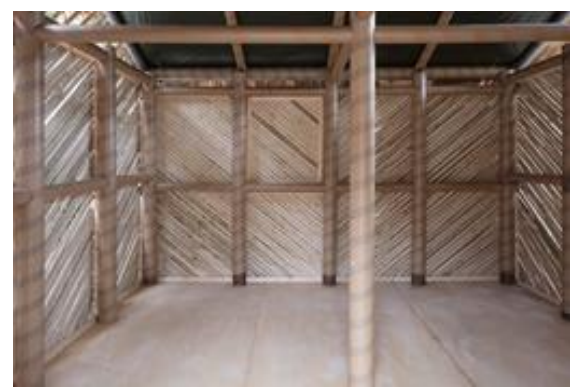

c. İçeriden görünüş (URL 7)

\section{Kenevir Betonu (HempCrete)}

Çevre koruma amacıyla geliştirilen başka bir malzeme de Kenevir Betondur. HempCrete adı verilen malzeme kenevir liflerinin kireç ile bağlanarak hafif beton benzeri bir malzeme şeklinde üretilmesi ile elde edilmektedir (URL 10). 
Güney Afrika'lı malzeme uzmanı Tony Budden ve ortağı Duncan Parker kenevir evinde en az karbon ayak izini elde etmeyi amaçlamıştır (Şekil 8 a). Bu üretimde kenevir lifleri kireç ve su ile bağlanarak blok oluşturulmakta ve bu bloklar yapı malzemesi olarak kullanılmaktadır (Şekil 10 b, c). Kenevir hızla büyüyen yenilenebilir bir kaynaktır ve bu malzemeden üretilen HempCrete blokları oldukça hafiftir. Bu malzeme karbon negatif olarak tanımlanmaktadır. $\mathrm{Bu}$ biyo-kompozit termal duvar kaplama malzemesinin inşaat teknolojini değiştirecek bir malzeme olduğu iddia edilmektedir. Artık dünyanın pek çok ülkesinde üretilmeye ve kullanılmaya başlanılmıştır (URL 8; 9).

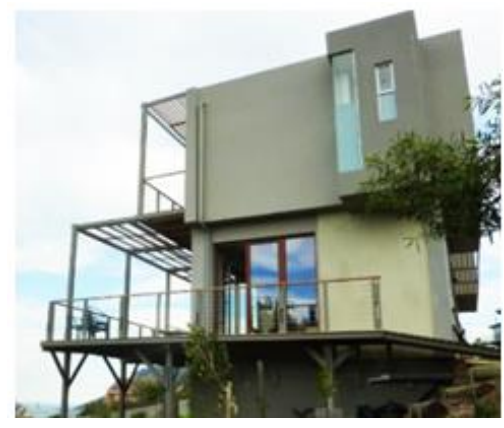

Şekil 8 a. Tony Budden'ın kenevir evi (Hempcrete) (URL 8)

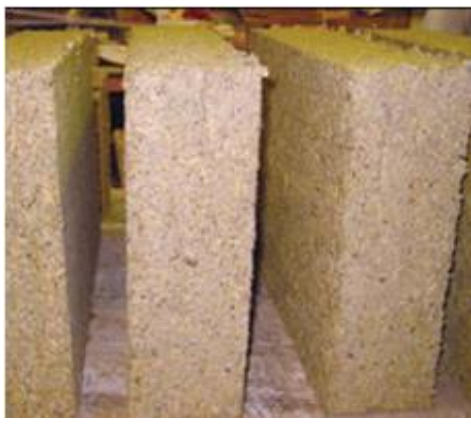

b. Kenevir beton bloğu

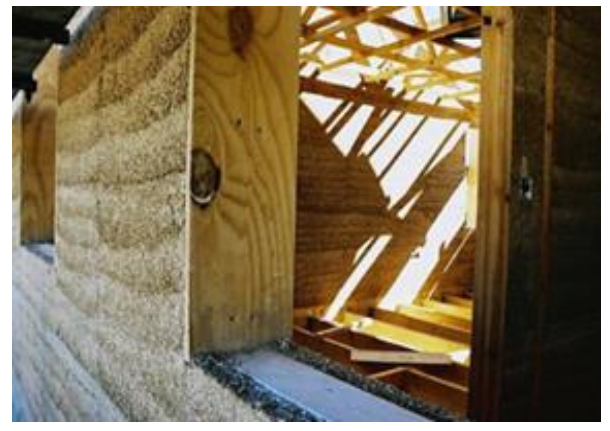

c. Kenevir betonun duvarda kullanımı

\section{Mantar tuğlası (Mycelium)}

Çevreci malzeme arayışlarından bir diğeri Mantar tuğlası (Mycelium) daha önce ambalaj sektöründe kullanılmakta idi. Mantar tuğlası (Mycelium) mantar ve mantarların kök yapısından oluşturulan kompozit bir yapı malzemesidir. Dayanıklı ve hafif tuğla boyutunda veya farklı formlar verilerek havada kurutulmaktadır. Biyo-fabrikasyon malzemelerin geliştirilmesi şeklinde üretilmiştir. Form verilerek kurutulan tuğla mukavemetli, suya, küfe ve yangına dayanıklı bir yapı malzemesidir. Hy-Fi olarak adlandırılan organik tuğla (myceliun) ile yapılan kule, New York'ta Mimar David Benjamin tarafından tasarlanmıştır. Kule müzik festivali süresince kullanılmak üzere geçici bir yapı olarak 2014'te yapılmıştır (Şekil 9). Mantar-tuğla teknolojisi 2007 de geliştirilmiş ama ilk kez bu boyutta Hy-Fy yapısında kullanılmıştır. Yapının kullanım süresi bittikten sonra mantar tuğlalar kompostlanarak geri dönüştürülmek üzere yapılmıştır. Bu ürün \%100 biyolojik olarak parçalanabilen dolayısı ile atık oluşturmayan bir üründür (URL 10; 11).

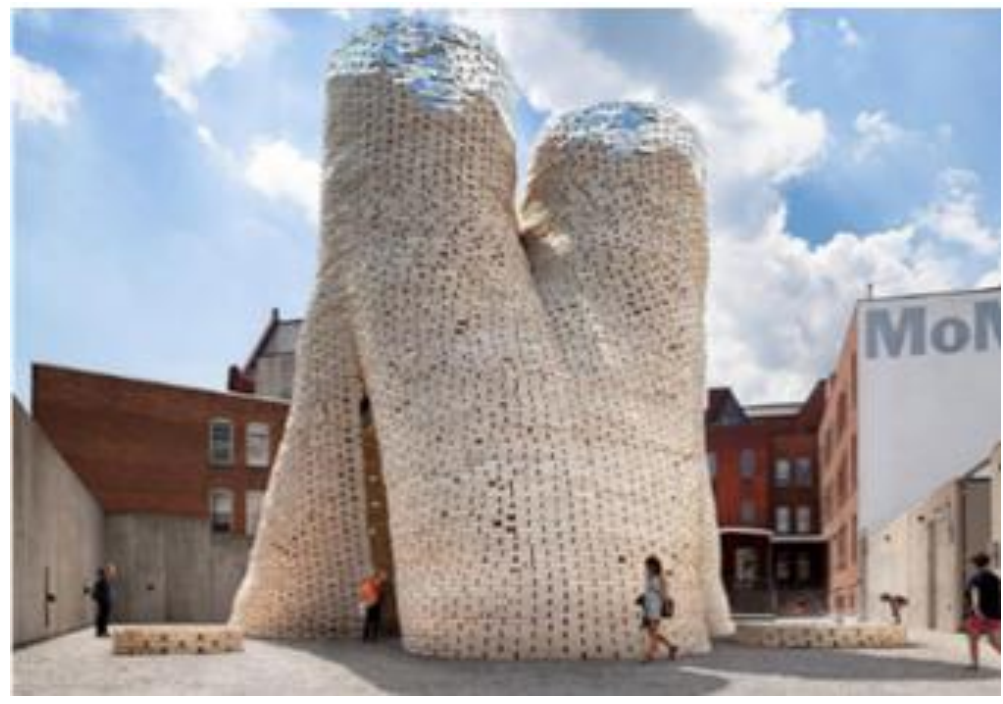

Şekil 9. Organik mantar-tuğla kulesi (URL 12) 


\section{Kereste Beton (Timbercrete)}

Yeşil yapı malzemesi olarak üretilen bir malzeme de Kereste Beton'dur (Timbercrete). Bu malzeme talaş ve beton karışımı ile elde edilen, betondan daha hafif bir yapı malzemesi olarak üretilmiştir. Tuğla ve döşeme kaplama elemanı olarak üretilebilmektedir. Kereste beton normal betondan daha hafiftir ve nakliyeye bağlı emisyonu azaltır. Talaş atıklarının kullanılmasını sağlamak amacıyla üretilmiştir. Şekil 10'da kereste beton malzemesinin yapıda kullanımı görülmektedir (URL 13).

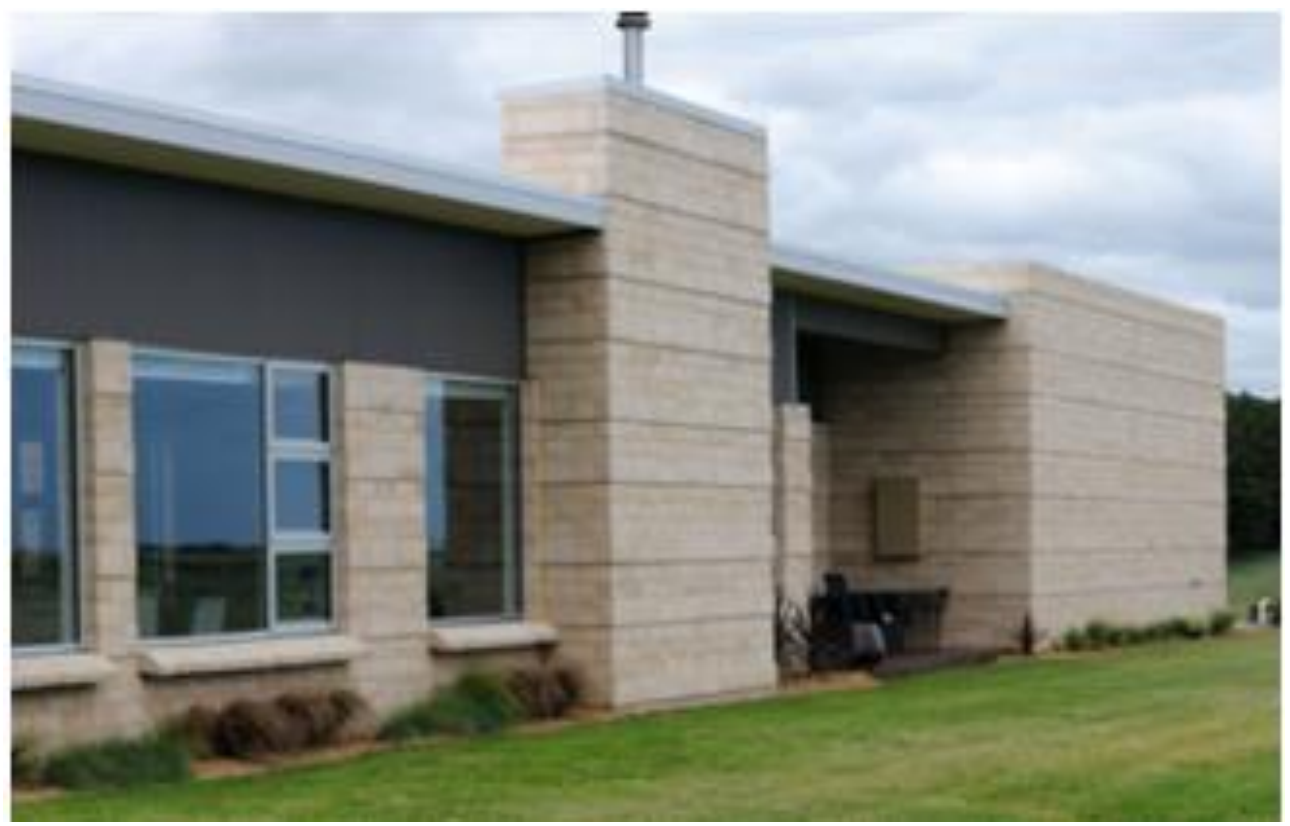

Şekil 10. Kereste beton (Timbercrete) malzemesinin yapıda kullanımı (URL 13)

Çevreci malzeme ve sistem arayışları çok geniş bir yelpazede sürdürülmektedir. Ancak burada amaç belli başlı örneklere değinerek bu tür çalışmalara dikkat çekmektir. Bu noktada aslında ikinci ve bir o kadar önemli olan çağdaş kerpiç yapılara yer verilmek istenilmiştir.

\section{2. Çağdaş Kerpiç Yapım Tekniği ve Uygulamaları}

Toprak binlerce yıldır insanların barınak yapmaya başlamasıyla birlikte yapı malzemesi olarak kullanılmaya başlanılmıştır. Günümüze değin farklı coğrafyalarda farklı tekniklerle uygulanmıştır. Uygulanan tekniklerin yanı sıra çağlar boyunca çeşitli uygarlıklar çeşitli katkılar ile toprağın dayanımını arttırmak için çalışmışlar farklı karışımlar kullanmışlardır. Genel olarak bakıldığında günümüzdeki çağdaş olarak adlandırdığı̆ız yöntemler ve malzemeler de temelde bu yapım sistemlerine benzemektedirler. Elbette ki günümüz uygulamalarında katkı maddeleri çeşitlenmiş ve zenginleştirilmiş, uygulanan kalıplar daha düzgün yüzeylerin elde edilmesine olanak sağlamıştır. Böylelikle daha çağdaş yapıların üretimi mümkün olabilmiştir. Bu bölümde farklı ülkelerde toprak malzeme olarak da adlandırılan kerpicin tasarım ve yapım tekniklerine, malzeme özelliklerine, sürdürülebilirlik açısından getirdiği faydalara yer verilecek ve bu malzeme ile uygulanmış çağdaş yapı örneklerine değinilecektir.

\section{1. Çağdaş Kerpiç Tasarım ve Yapım Tekniği}

Kerpiç malzeme kullanılarak yapılacak yapıların tasarımı iki farklı şekilde uygulanabilmektedir. Bunlardan ilki geleneksel yapılarımızda kullanılmakta olan yığma yapım tekniği veya ahşap karkas uygulamasında duvar dolgu malzemesi olarak kullanımı şeklindeki uygulamalardır. Bu sistemlerin uygulanması halinde açıklık geçme yani mekan boyutlandırma kısıtları söz konusudur. Bu tür bir uygulama için yapılan tasarımda açıklık mesafelerinin bir yönde ortalama dört metre ile sınırlandırılması ve diğer yönün istenen mesafeye çıkarılabilmesi ile tasarım 
yürütülebilmektedir. Ayrıca kerpiç, yığma yapım tekniğinde kullanılacak ise duvar kalınlıklarının döşemeleri taşıması açısından ortalama $50 \mathrm{~cm}$ genişliğinde tutulması önerilmektedir. Bu tasarım ilkelerine göre daha küçük mekanların kullanılacağı yapıların üretimi uygun görülmektedir. Yani bu sistemde geleneksel yapım yöntemleri için uygulanan tasarım kuralları geçerlidir. İkinci uygulamada ise kerpiç sadece duvar malzemesi olarak kullanılmaktadır. Bu yöntemde strüktür istenen malzeme ve teknik ile oluşturulabilmektedir. Taşıyıcı iskelet sistem kurulduktan sonra kerpiç duvar malzemesi olarak kullanılmaktadır. Bu uygulamada taşıyıcı sistem betonarme, çelik ahşap vb. ile istenen boyuta ulaşabilen açıklıklarla yapılabilmektedir. Bu tür tasarımlarda kerpiç duvarların tasarım açısından getirdiği sınırlama düş̧ey yönde eğri yüzeylerin oluşturulmasındaki kısıtlılıklardır. Düşey yönde duvar yine de yığma sistem gibi davranacağından aşağıdan yukarıya doğru azalan bir genişlik ile yüzeyde eğim yapmak mümkündür ancak tersi söz konusu olamamaktadır. Bununla birlikte yatay yöndeki eğimli yüzey tasarımı bu malzeme ile mümkündür. Kerpiç malzeme ile uygulanmış örnekler incelendiğinde yatay yönde eğri yüzey kullanımı pek çok örnekte görülmüştür. Bunlardan biri de çalışmada örnekler bölümünde yer alan Göbeklitepe sosyal tesisleridir.

Ülkemizde yaygın olarak geleneksel kerpiç yapım yönteminde toprak, saman ile karıştırılarak havuzda dinlendirildikten sonra daha önceden hazırlanan kalıplara yerleştirilir. Sonrasında kuruma amaçlı bekletilir. Elde edilen kerpiç bloklar daha sonra inşaat alanına taşınır ve aynı zamanda duvar oluşturmak için de bu blokların örülmesi gerekmektedir. Bu uzun ve işçilik gerektiren bir süreçtir. Bu geleneksel yöntemin dışında günümüzde hazırlanan kalıplara doğrudan toprak harcın dökülmesi ve kalıpta sıkıştırılması yöntemi kullanılmaktadır. Bu yöntem ile çok daha kısa sürede ve çok daha az işçilikle yapı üretimi gerçekleştirilebilmektedir.

Bu teknik için kullanılan kalıplar pek çok kez kullanılabildikleri için minimum atık oluşturmaktadırlar. Bu teknikte sıva, duvar kağıdı gibi örtülere gerek yoktur, duvar kendi katmanlı dokusu ile kullanım için yeterli temizliğe sahiptir. $\mathrm{Bu}$ özelliği ile de toprağın çok ekonomik ve sürdürülebilir bir malzeme olduğu görülmektedir (URL:1).

Çok katlı yapılar için betonarme ya da çelik yapı teknolojisi kullanmak zorunlulukken üç dört kat gibi daha az katlı yapılar için toprak yapılar tercih edilebilir. Çağdaş yapım yöntemleri ile toprak yapı üretimi hem kısa sürede hem dayanıklı hem de farklı görsel özellik ve renk kullanmayı mümkün kılmaktadır. Bu teknikler karma yapım yöntemleriyle kombine edilerek kullanılabilirken tümüyle toprak ile de yapılabilmektedir. Genel olarak sıkıştırılmış toprak (rammed earth) yaygın bir çağdaş kerpiç yapım yöntemidir. Bu yöntemler dışında kalıplanmış kerpiç ile yığma yöntemde duvar örülerek ya da kerpiç boyutlarında sıkıştırılmış blok şeklinde (compressed earth blocks) veya panel olarak da üretilebilmektedir (Perker ve Akkuş, 2019).

Çağdaş kerpiç yapım yönteminde yapı temeli için betonarme veya taş yığma temel uygulanabilmektedir. Yapı için temel atıldıktan sonra temel üzerine istenen duvar genişliğinde kalıplar yerleştirilmektedir. Yapının türüne, kat yüksekliğine ve plan tipine göre değişiklik göstermekle birlikte genel olarak taşıyıcı duvarların $50 \mathrm{~cm}$ kalınlığında olması önerilmektedir. Kalıpların duvar hizasının temelin dış yüzünden içeride kalmayacak şekilde yerleştirilmesi gerekmektedir. Duvarlar için, genellikle perde duvar yapımında kullanılan çelik kalıp eğer çelik kalıp yoksa içi düzeltilmiş ve yalıtılmış ahşap kalıp türü kullanılabilmektedir (Şekil $11 \mathrm{a}, \mathrm{b}$ ). Kalıpların yerleştirilmesinden sonra toprak istenen katkılar (su, alçı, kireç vb.) eklenerek elde veya mikser aracılığı ile kalıba dökülebilecek sertlik ve kıvamda karıştırılmaktadır (Şekil 12 a, b, c) (Işık, 2011).

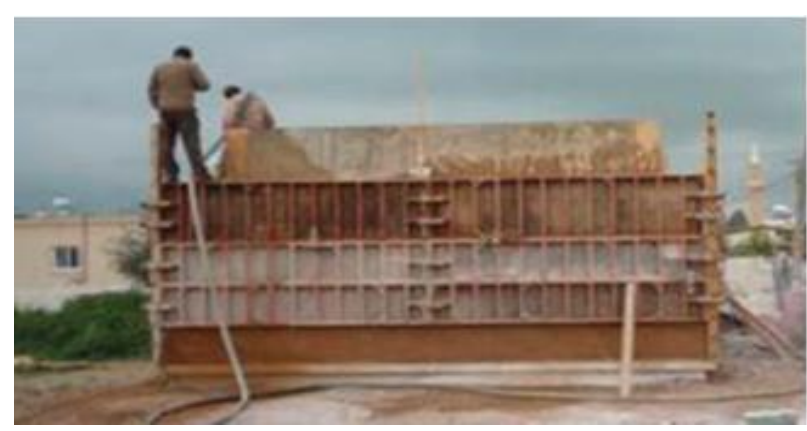

Şekil 11 a. Çelik kalıp kullanımı (Işık, 2020)

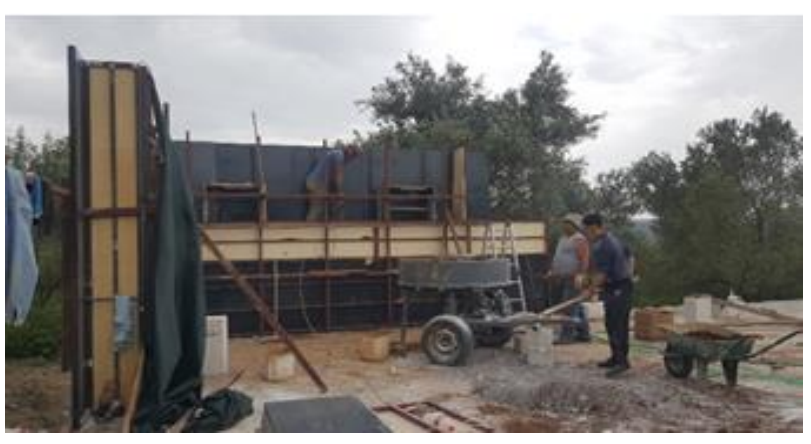

b. Ahşap kalıp kullanımı (Aysel Tarım)

Materials and Production Techniques in Environmental Approaches; Contemporary Adobe Buildings

Journal of Urban Academy | Volume: 14 Issue: 2 | ISSN: 2146-9229

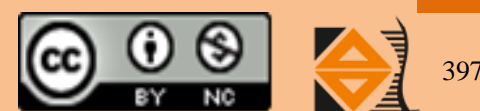




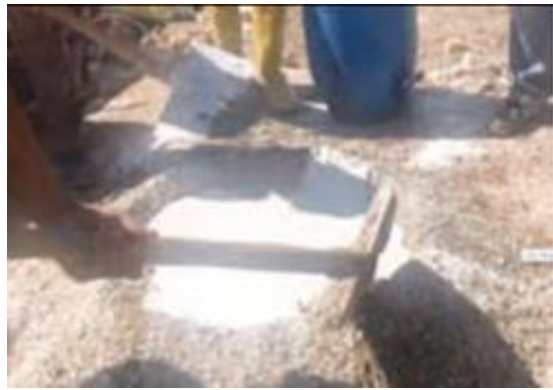

Şekil 12 a. Toprağın döküm öncesi katkılarının ilave edilmesi

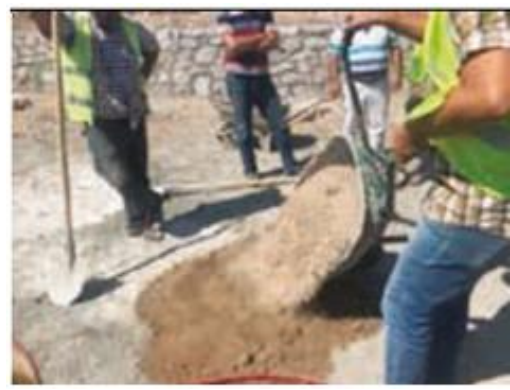

b. Elle karıştırılması (Yardıml, Işık, ve Balık, 2018)

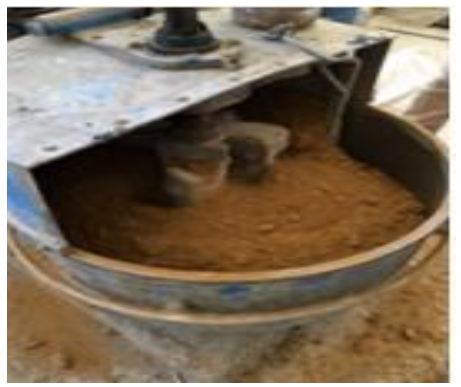

c. Toprağın mikser ile karıştırılması (Yardımlı vd., 2017)

Toprağın karışımı püskürtme yöntemi ile yapılacaksa karışım shotcrete makinesinde (Şekil 13 a) hazırlanarak toprak harç kalıbın içine basınçla püskürtülmektedir (Şekil 13 b). Püskürtme yönteminde yapım süresi çok kısa sürede tamamlanabilmektedir. Püskürtme yöntemi dışında yaygın olarak kullanılan kalıp içinde tokmaklanarak sıkıştırma yöntemi de kullanılmaktadır (Şekil 13 c).
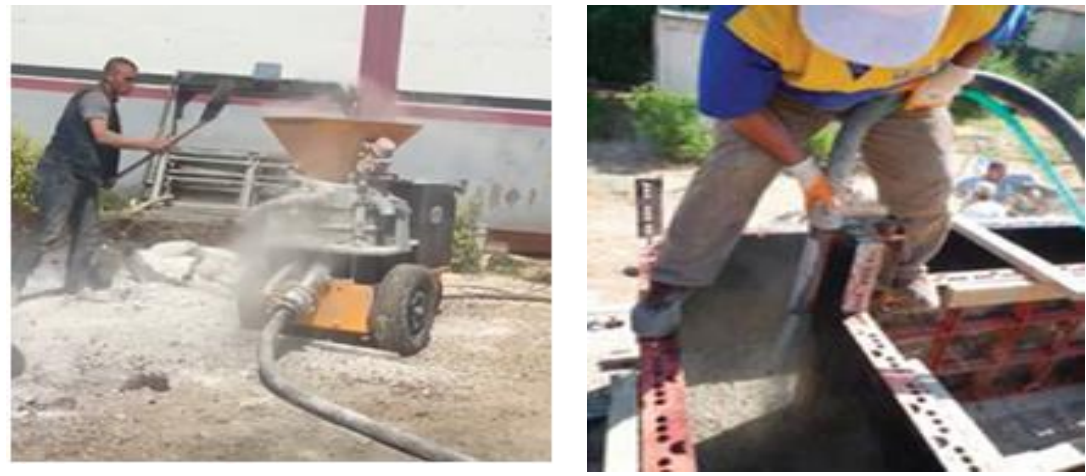

Şekil 13 a. Shotcrete makinesi kullanımı b. Püskürtme yöntemi ile duvar yapımı (Işık, 2020)

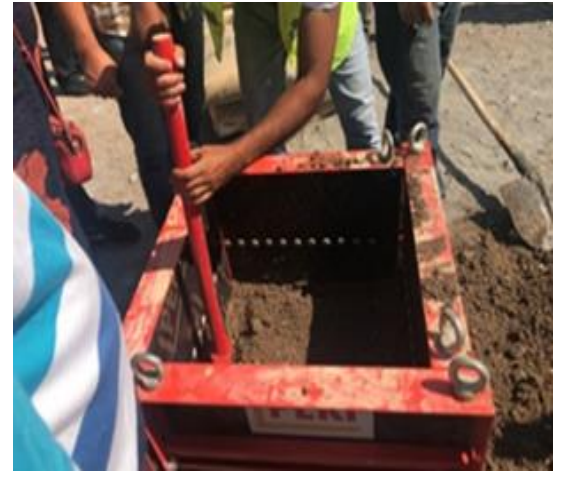

c. Toprağın kalıp içine tokmaklanarak yerleştirilmesi (Yardımlı, vd. 2018)

Çağdaş yapım yöntemi ile toprak yapı üretiminde, kerpiç hazırlama süreci ortadan kalkmakta böylece hem kerpiç blokların oluşturulması hem de malzemenin taşınması ve inşaatta duvar örülmesi gibi işçilikler yer almamakta inşaat çok daha ekonomik ve kısa sürede yapılabilmektedir (Işık, 2011).

\subsection{Kerpiç Malzeme Özellikleri}

Kerpiç kum, silt, kil, organik ve inorganik agregaların karışımına şekil verilerek üretilen bir yapı malzemesidir (O’Grady, Luke, Mokrišová, ve Roosevelt, 2018) dolayısı ile oldukça ekonomiktir. Bazı durumlarda yapı üretiminde kullanılacak kerpiç için gerekli toprak, kil oranının uygunluğu açısından bölgede yakın bir alandan getirilirken bazen temelin kazılması ile çıkarılan toprak ta kullanılabilmektedir. Taşıma ve üretim için enerji gerektirmemekte, üretim ve taşımaya bağlı çevre kirliliğine neden olmamaktadır (Sezer ve Arpacıoğlu, 2020).

Kerpiç yapı için kullanılacak toprağın killi (kohezyonlu) veya marnlı, puzolanlı ve kumlu olması gerekmektedir (Türküresin, 2017). Toprak yap1 malzemesi her zaman istenen özellikte bulunmayabilmektedir. Bu nedenle malzemeyi güçlendirmek ve uygun hale getirmek için bazı katkılar koymak çözüm olabilmektedir. Toprağın basitçe analizi için, hafif nemli iken avuçta sıkmak onun yapısı hakkında fikir vermektedir. Eğer yeterli kil miktarına sahipse

Materials and Production Techniques in Environmental Approaches; Contemporary Adobe Buildings

Journal of Urban Academy | Volume: 14 Issue: 2 | ISSN: 2146-9229

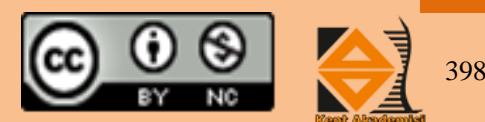


avuçta aldığı şekli koruyacaktır (Şekil 14 a) ve yere düşürüldüğünde parçalanmayacaktır (Şekil 14 b). Eğer kil miktarı azsa yere düşürüldüğünde parçalanır bu durumda kil ilave etmek gerekmektedir. Eğer toprak harç ele yapışırsa ve kuruduğunda çatlarsa kil miktarı fazla demektir bu durumda da harca kum katmak gerekmektedir (URL 14; Yardıml,, Işık, Arslan, ve Samurkaş, 2017). Aynı zamanda elde toprağa küçük bir silindir şekli verilip yarısı boşluğa gelecek şekilde masa üzerine yerleştirildiğinde silindirin masanın dışında kalan bölümü kırılıp düşmüyorsa ve şeklini koruyorsa yine bu toprak, kerpiç yapı için uygun olarak değerlendirilmektedir (Şekil 14 c).

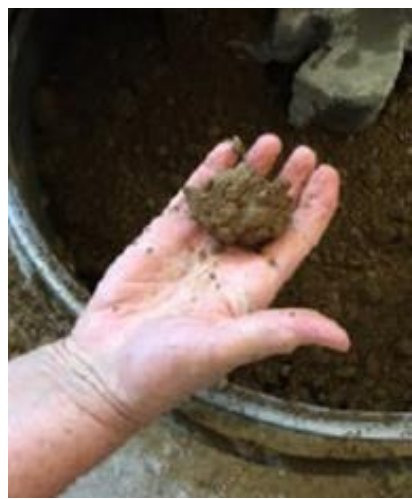

Şekil 14 a. Toprağa elde şekil verilmesi

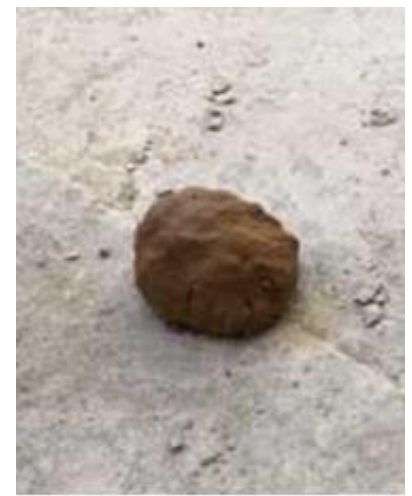

b. Toprağın yere düştüğünde parçalanmaması

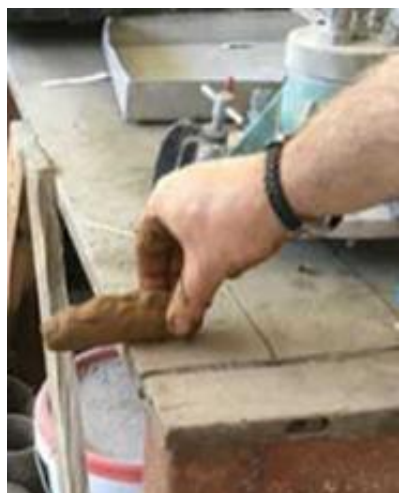

c. Şeklindeki toprağın açıkta kalan bölümünün kırılıp düşmemesi

Geleneksel yöntemle üretilen kerpiç için bitkisel lif olarak saman kullanımı oldukça yaygın bir uygulamadır, bunun dışında kireç kum vb. malzemeler de katılmaktadır. Ancak günümüz uygulamalarında daha mukavemetli bir harç oluşturmak için bazı karışımlar kullanılmaktadır. Toprağın iyileştirilmesi sayesinde daha mukavemetli bir malzeme elde edilir, su ve neme karşı dayanımı artar, toz ve kir üretmez, kuruması sürecinde çatlaklar oluşmaz (Acun Özgünler ve Gürdal, 2012).

Toprağın iyileştirilmesi konusunda yapılmış pek çok çalışma bulunmaktadır. Bir çalışmada toprağa fiber naylon katkı eklenerek basınç dayanımı arttırılmıştır (Binici, Durgun, ve Yardım, 2010). Yapılan başka bir çalışmada toprağa enzim ve polimer katılarak deneysel çalışma yapılmış ve her iki malzeme de basınç deneylerinde ve suya karşı dayanımlarında malzemeyi daha dayanıklı hale getirmiştir (Yardımlı vd. 2017). Bazı çalışmalarda çimento katkısı da kullanılmaktadır. Bu oranın \%10 miktarında kullanımı halinde en iyi dayanımın elde edildiği belirtilmiştir, başka bir deneysel çalışmada \%30 çimento ve \%6 kireç karıştırılarak kuru tek eksenli deneyde $16 \mathrm{MPa}$ basınç dayanımı elde edilmiştir. Bulunulan bölgeye de bağlı olarak hurma lifleri, pirinç samanı, muz lifleri gibi pek çok malzeme ile de çalışılmıştır (Sayed, 2020).

İTÜ'de Prof. Ruhi Kafesçioğlu tarafından geliştirilen ALKER adı verilmiş toprak malzemenin de daha dayanıklı olduğu bilinmektedir. Alker toprağın killi olma durumuna veya içeriklerine göre belirlenen miktarlarda kireç ve alçı katılarak harcın güçlendirilmesi ile elde edilen malzemedir (Işık 2011; URL 15).

\subsection{Kerpiç Yapıların Sürdürülebilirlik Özellikleri}

Sürdürülebilirlik genel olarak gelecekte kullanılabilecek enerji ve malzemeleri tüketmeden yapının kendi gereksinimini karşılaması olarak tanımlanmaktadır. Mimarlıkta bu anlamda sürdürülebilirlik genel olarak yapıların üretim süreci ve binaya yerleşimden sonraki tüketim açısından ele alınmaktadır. Doğal kaynakların mümkün olduğunca az kullanımı yapının işletilmesi sürecindeki tüketimi bir yapının sürdürülebilir olmasındaki temel yaklaşımlardır. Bu yaklaşımların ikisi de önemli ve aslında birbirleri ile de zaman zaman ilişkili olabilmektedir. Bir yapının inşaa edilmesi sürecinde henüz içinde yaşanmaya başlanılmadan yaşam döngüsüne tüm karbonun \%70 gibi bir miktarı salınmaktadır. Bu oldukça yüksek bir orandır. Yaşam döngüsü boyunca ise binada kullanılan enerjinin \%90'1 1sıl konfor ve aydınlatma için kullanılmaktadır (Silver ve Mc Lean, 2013). 
Betonarme bir yapının üretim sürecinde kullanılan demir, çakıl, çimento gibi temel malzemelerin üretimlerinin hepsinde doğaya karbon salınımı gerçekleşmektedir. Buna karşın kerpiç malzemenin üretiminde herhangi bir karbon salınımı söz konusu değildir. Aynı zamanda betonarme yapıların geri dönüşümü sürecinde tam bir dönüşüm olamamakta ve micır ya da agrega gibi kullanılabilmesi için de yine betonun parçalanma sürecinde bir enerji kullanımı gerekmektedir. Kerpiç yapıların yıkılması halinde ise yapıda kullanılan toprak malzeme hiçbir atık oluşturmamaktadir.

Yapının yaşam döngüsü sürecindeki enerji tüketimi açısından bakıldığında da günümüz betonarme yapılarında hem betonun hem tuğla duvarların 1sı geçirgenliklerinin fazla olması nedeniyle ciddi bir oranda 1sı yalıtım gereksinimi göstermektedirler. Buna karşın kerpiç yapıların duvar kalınlıkları fazla olduğu ve toprak duvarın ısı iletkenliği az olduğu için ısıl konfor açısından oldukça ekonomik bir yapı malzemesidir ve ayrıca yalıtım gereksinimi göstermemektedirler. Pete Silver ve Will Mc Lean Mimarlık Teknolojisine Giriş kitabında kerpiç için kullanılan kil ve samanın kalıplara dökülmesi ile elde edilen panellerin günümüzde yapıların ısı yalıtımı için cephe kaplama sistemi olarak kullanıldığına yer vermiştir (Silver ve Mc Lean, 2013). Ayrıca kerpiç duvarlar gün boyunca güneş 1sısını toplamakta ve gece serin olduğunda bu 1sıyı içeriye yayarak ısıl konforu sağlamaktadır. Kışın daha sıcak yazın daha soğuk kalarak ekonomik ve çevreci bir özellik göstermektedirler (URL 1). Nemi dengeleyerek sağlıklı yaşama ortamı sağlamaktadırlar. Aynı zamanda, konut ve yapı dışında da kullanılması ile ilgili çalışmalar bulunmaktadır. Örneğin Kıbrıs, Büyükkonuk eko festival programı kapsamında belediye durağı olarak yapılmış ve ilgi görmüştür (Güner, Benli, ve Karaçar, 2019).

Tüm bu çevre kirliliği kriterlerine ve enerji etkin yapı çözümlerine bakıldığında aslında kerpiç yapılar pek çok açıdan bu kriterlere göre oldukça çevreci yapılar olarak karşımıza çıkmaktadır (Yardımlı, Shahriary ve Güleç Özer, 2018). Yakın mesafeden malzeme temini, kalın duvarları ile 1sı korunumu sağlaması, toprak yapıların nem dengeleyici olması, sağlıklı ve ekonomik olması, yapımında enerji kullanımı gerektirmemesi ve atmosfere $\mathrm{CO}_{2}$ gibi zararlı gazların salınımına neden olmaması (Berge, 2009; Çavuş, Dayı, Ulusu, ve Aruntaş, 2015) yapının ömrü bittiğinde toprak olması nedeniyle atık oluşturmaması ve çevreyi kirletmemesi en önemli özelliklerdir. Kerpiç yapıya günümüzde tereddütle yaklaşılmasının nedeni depreme ve suya dayanıksız bir malzeme olduğu hakkında bir kanının olmasıdır. Ancak tekniğine uygun yapılması ve bazı önlemler alınması ile bu olumsuzluklar giderilebilmektedir (Yardımlı ve Dal 2016).

Aynı zamanda bu yapıların çok uzun ömürlü oldukları da görülmektedir. M.Ö. 7400 yılında kurulmuş olan Çatalhöyük kerpiç yapıların olduğu bir antik kenttir ve yapı duvarları günümüze kadar ulaşmıştır (URL 16). Yine çok sert iklim koşullarına rağmen M.Ö. 840 - 825 tarihlerinde kurulmuş Van kalesi kerpiç bir yapıdır ve günümüzde hala ayaktadır (URL 17). Bu örnekler çok daha fazla arttırılabilir elbette burada amaç kerpiç yapıların aslında ne kadar dayanıklı olduklarını göstermektir.

Kerpiç bina yapım tekniğine uygun üretildiğinde depreme dayanıklı bir yapı malzemesidir. İ.T.Ü. Maslak kampüsü içinde, 1995 yılında INTAG TOKİ 622 nolu Kerpiç 02 Arge Binası olarak Prof Dr. Bilge Işık tarafından yapılmış kerpiç yap1 1999 İzmit depremini hasarsız olarak atlatmıştır. Kerpiç yapıların deprem güvenliği için Ankara Afet İşleri Genel Müdürlüğünde Bilge Işık tarafından yapılmış sarma tablası deneyi, 7 derece şiddetinde depreme karşı kerpiç yapının ayakta kaldığını göstermiştir. Deney için sarsma tablası üzerine yapılan yapı 4X5 m boyutlarında olup duvarları püskürtme yöntemi ile yapılmıştır ve deney sonucunda yapıda yıkılma olmamıştır (Işsk, 2020). Ayrıca yapılan çalışmalar duvar yüzeyinde L çubuklar, ağ gibi malzemeler ile takviye edilen kerpiç yapıların depreme daha dayanıklı hale getirildiklerini göstermiştir (Bhattacharya, Nayak ve Chandra Dutta, 2014).

\section{4. Çağdaş Kerpiç Yapı Örnekleri}

Günümüzde çevre korumaya yönelik yapı üretim araştırmaları sürecinde kerpiç yapılara yeniden yönelim olmakta ve tüm dünyada bu çalışmalar sürdürülmektedir. Bu bölümde hem ülkemizden hem dünyadan çağdaş kerpiç yapılara örnekler verilmek istenilmiştir.

\subsubsection{Türkiye'deki Çağdaş Kerpiç Yapı Örnekleri}


Çevreci yaklaşımlarla ülkemizde hem bireysel küçük yapılarda hem daha büyük ve kurumsal yapılarda çağdaş yöntemle kerpiç yapı üretimi çok yaygın olmamakla birlikte yapılmaktadır. Ülkemizde bu anlamda yapılmış birkaç örneğe aşağıda yer verilmiştir.

\section{Hakan Kök At Çiftliği Projesi}

Cengiz Bektaş at çiftliği için uygun malzemenin kerpiç olduğunu belirtmektedir. Aynı zamanda en sağlıklı malzeme olduğunu, havayı temizleyen ve nem oranını \% 8-12 arasında tutan toprak yapıların insanlar için sağlıklı olma koşullarını sağladığını da açıklamıştır. Projelendirilen at çiftliğinde toprağın kalıba dökülmesi yerine kerpiç bloklarla örme tekniği kullanılmıştır. Örgü için kullanılan kerpiç boyutunu Cengiz Bektaş kendisi 12/26/9 olarak belirlemiş, bloklar bu boyutta üretilerek duvarlar örülmüş̧ür. Yapı büyük açıklıklı olarak ahşap çatı ile kapatılmıştır (Şekil 15 a, b). Yap1 duvarları ahşap hatıllarla güçlendirilmiştir (Şekil 15 c) (Kaplan 2020).

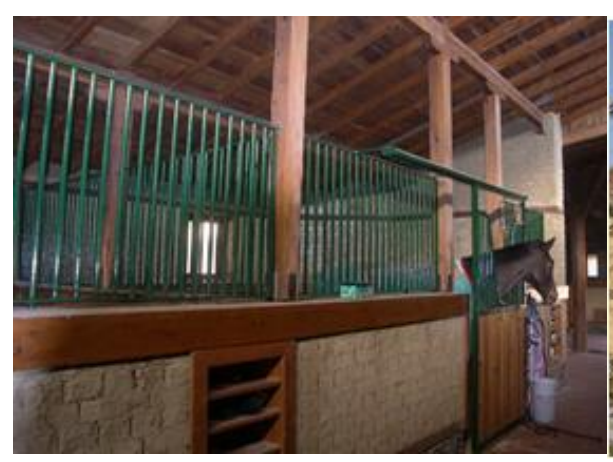

Şekil 15 a. Çatı örtüsü (Bektaş, 2019)

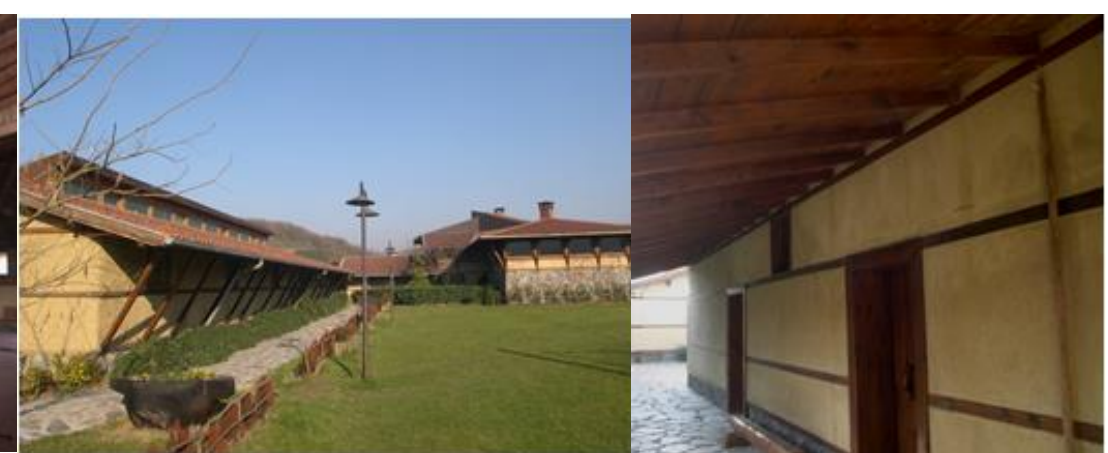

b. Yapıyı örten çatının genel görünüşü (Bektaş, 2019). c. Duvarda hatıl kullanımı (Bektaş, 2019).

\section{Şanlıurfa Göbeklitepe Sosyal Tesisleri}

Şanlıurfa'da bulunan ve dünyanın en eski inanç merkezi olarak bilinen Göbeklitepe insanları büyüleyen tarihi bir kalıntıdır. Böylesine önemli bir merkez için yapılmış sosyal tesislerin de bu çevreye uyumlu olması önemlidir. Bu amaçla sosyal tesis projesi açılan ulusal bir yarışma ile belirlenmiştir. Yarışmayı kazanan proje iki bloktan oluşturulmuştur (Şekil 16). Bu iki blok Göbeklitepe'de bulunan tapınakların dairesel planlamasından etkilenerek dairesel olarak tasarlanmıştır. Bu yapının duvarları için bulunduğu yerle uyumu da düşünülerek sıkıştırılmış toprak malzeme uygulanmıştır (URL 18). Çağdaş kerpiç yapım tekniği ile üretilen duvarlar için Prof. Dr. Bilge Işık'tan danışmanlık desteği alınmıştır.

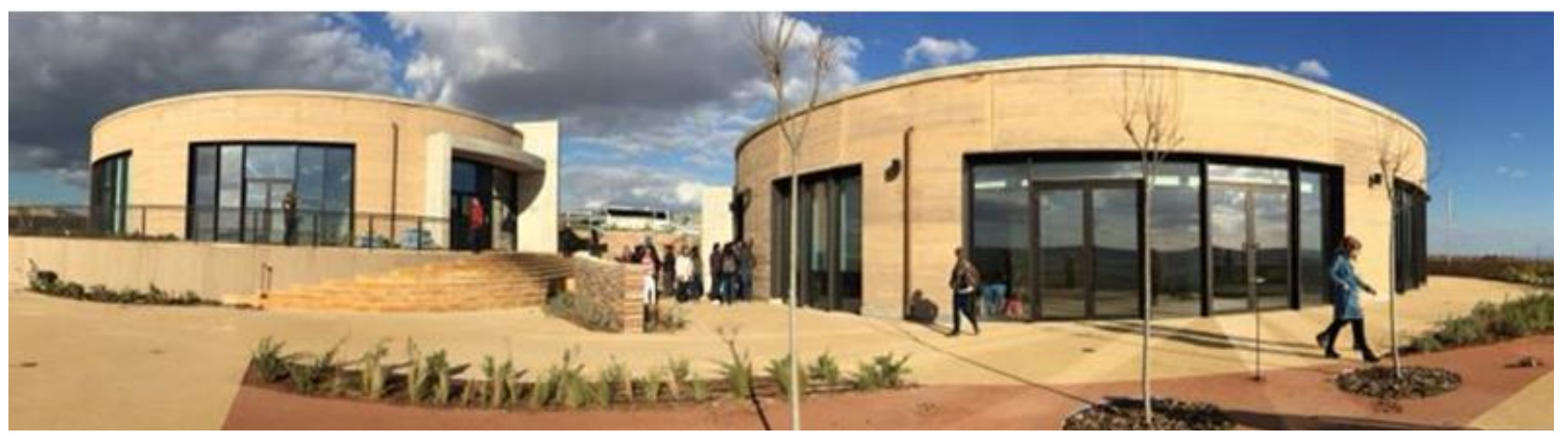

Şekil 16. Göbeklitepe sosyal tesisleri

\section{İTÜ Ayazağa Kampüsünde Konut örneği}

Materials and Production Techniques in Environmental Approaches; Contemporary Adobe Buildings

Journal of Urban Academy | Volume: 14 Issue: 2 | ISSN: 2146-9229

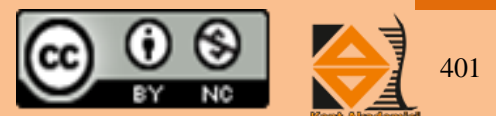


Yapı, 26 yıl önce İTÜ Ayazağa kampüsünde TÜBİTAK INTAG TOKİ 622 projesi kapsamında Prof Dr. Bilge Işık tarafından 1995'te yapılmıştır. Yapım tekniği olarak kalıp içine sıkıştııılmış toprak yöntemi kullanılmıştır. 1999 Marmara depreminde hiçbir hasar almamış ve kerpiç yapıların uygun tekniklerle yapıldığında depreme dayanıklı olduğunu göstermiştir. Yapı hala ayaktadır ve yapıldığı günden itibaren çeşitli hizmetlerde kullanılmıştır (Şekil 17).

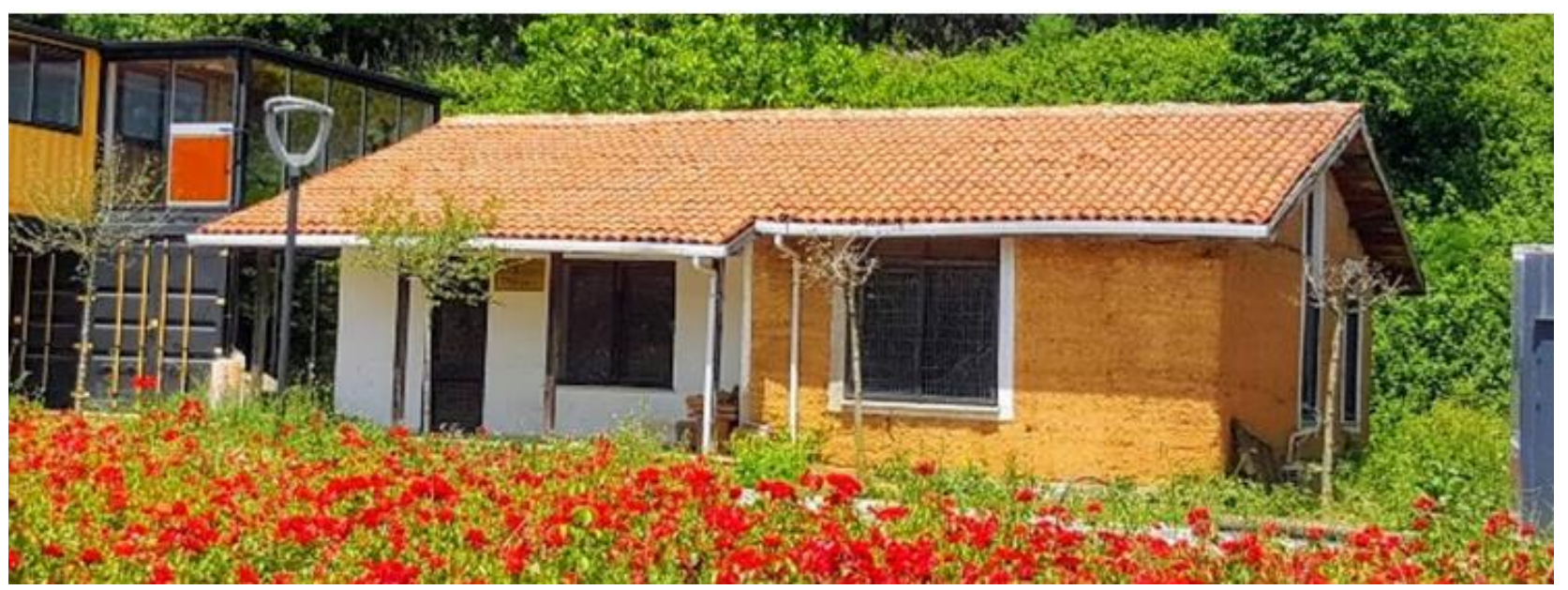

Şekil 17. İTÜ Ayazağa kampüsünde kerpiç yapı (Bilge Işık)

\section{Muğla Köyceğiz'de Film Platosu}

Muğla Köyceğiz'de sanat köyü olarak kurulmuş Film Platosunda da kerpiç kullanılmıştır (Şekil 18 a, b, c). Yapının büyük açıklık geçen bölümlerinde taşıyıcı olarak çelik strüktür ve duvarların yapımında kerpiç kullanılmıştır. Yapının bulunduğu bölüm zaman zaman su baskınlarına uğramaktadır. Bu su baskınlarına rağmen yapı duvarlarında herhangi bir hasar meydana gelmemiştir. Bu örnek yapı da kerpiç yapıların suya karşı dayanımının bu sıkıştırma tekniği sayesinde güçlendiğini göstermektedir.

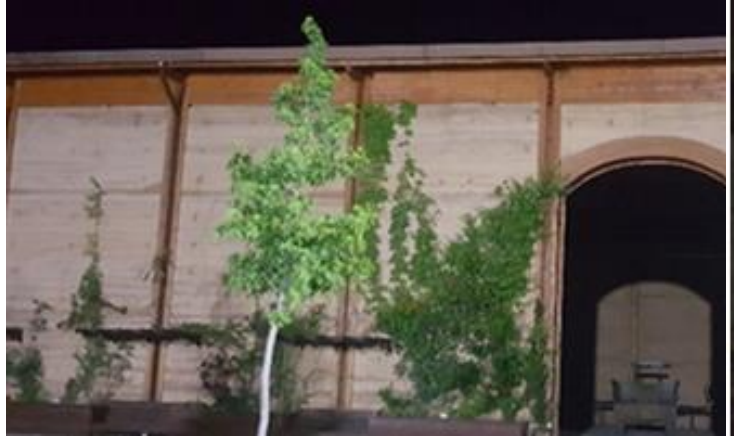

Şekil 18 a. Köyceğiz film platosu ön görünüşü (Aysel Tarım)

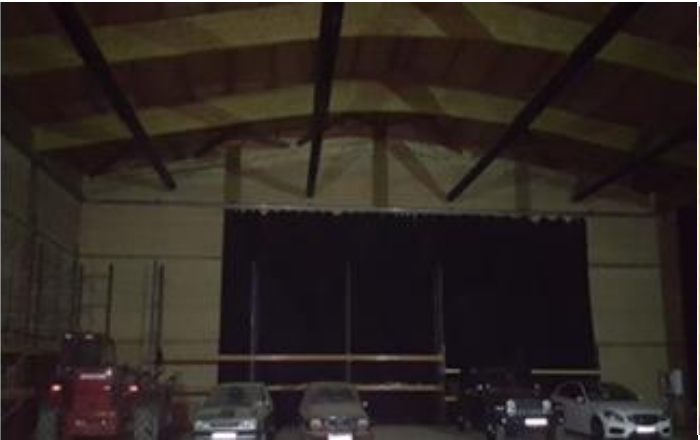

b, İç mekandan görünüş (Aysel Tarım)

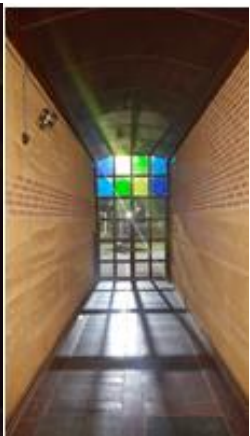

c. İç mekandan koridor (Aysel Tarım)

\section{Anadolu Meleği Kadın Eğitim ve Üretim Merkezi}

Mimar Özgül Öztürk Elazığ'da yaptığı Kadın Eğitim ve Üretim Merkezinde ekolojik olması açısından toprak yapı projesi hazırlamış ve uygulamıştır. Yapı çağdaş kerpiç yöntemi olarak uygulanan çelik kalıp kullanılarak üretilmiş ve duvarlarda düzgün yüzeyler elde edilmiştir (Şekil 19). Yapı, tamamlandıktan sonra yaşanan Elazığ depreminde hiç hasar almamış ve deprem sürecinde depremzedeleri konuk etmiş̧ir. Mimar Öztürk Ekolojik mimari örneği olarak yaptı̆̆ı bu yapıyı yerel ve doğal malzemeler ile üretilen, az enerji gereksinimi gösteren, sağlıklı, ekonomik ve kolayca

Materials and Production Techniques in Environmental Approaches; Contemporary Adobe Buildings

Journal of Urban Academy | Volume: 14 Issue: 2 | ISSN: 2146-9229

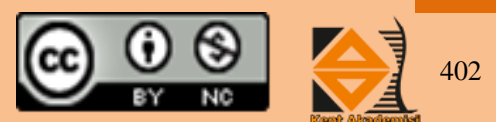


bakımı yapılabilen bir yapı olarak tanımlamıştır. Mimari özellikleri açısından, yapı enerjisini güneşten sağlamaktadır. Çatısı yeşil çatı olarak düzenlenmiş ve yağmur suyunu biriktirerek hidrofor ve rezervuarlarda kullanımını sağlamıştır. Yapının banyo ve tuvaleti Anadolu evinden esinlenilerek bahçeye yapılmıştır (Akbaş 2020).

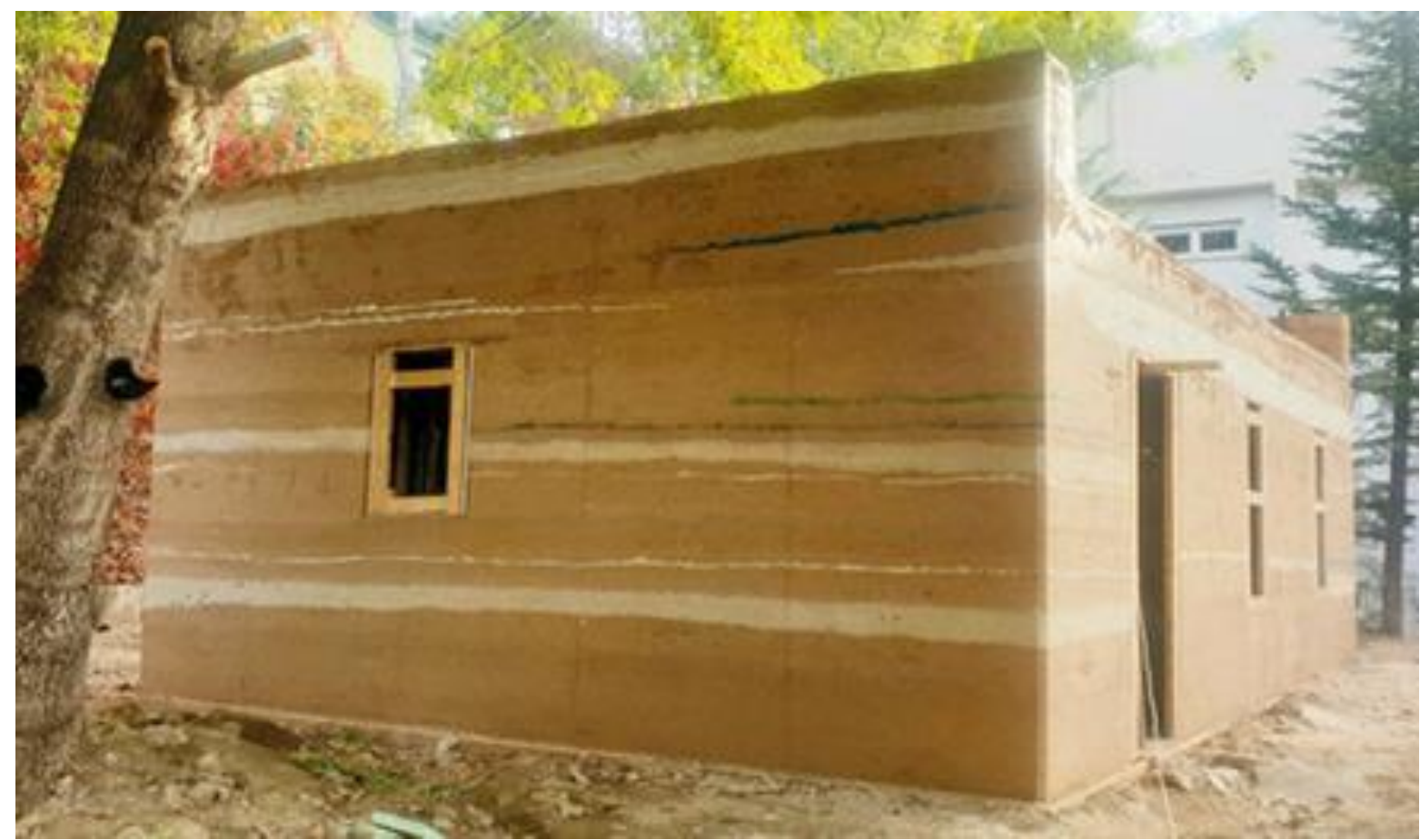

Şekil 19. Mimar Özgül Öztürk'ün Elazı̆̆’da topraktan yaptığı bina (URL 19).

\subsubsection{Dünyadaki Çağdaş Kerpiç Yapı Örnekleri}

Günümüzde çağdaş kerpiç yapı uygulamaları dünyanın çeşitli bölgelerinde yine çeşitli katkı ve yenilik denemeleriyle uygulanmaya devam etmektedir. Örneğin Earth Structures Africa adlı firma taşocağı agregası, çimento ve su katkısı kullanarak duvar kalınlığını 30 cm'ye kadar indirmiştir (Şekil 20 a, b). Bu duvar kalınlığına rağmen ek bir strüktür kullanmadan yapıyı yığma olarak yapmaktadır. Firma tarafından nefes alan ve kimyasal içermeyen bu duvarların dört saate kadar yangına dayanıklı olduğu belirtilmiştir (URL 1). Çalışmanın bu bölümünde dünyadan birkaç örneğe sırasıyla yer verilmiştir.
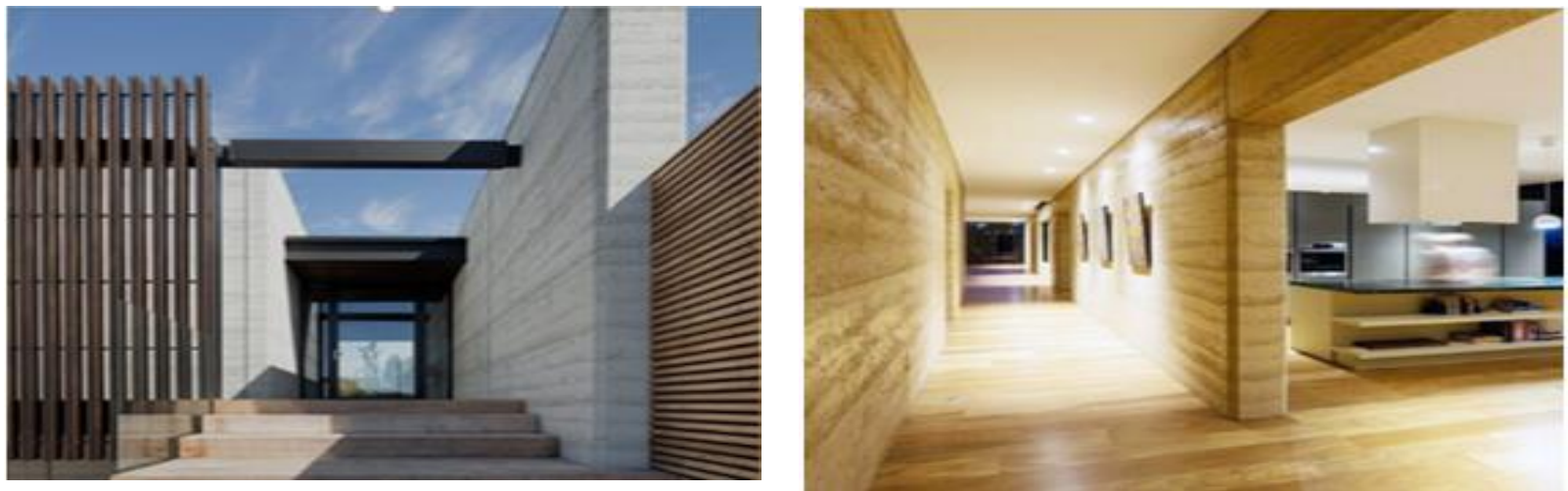

Materials and Production Techniques in Environmental Approaches; Contemporary Adobe Buildings

Journal of Urban Academy | Volume: 14 Issue: 2 | ISSN: 2146-9229

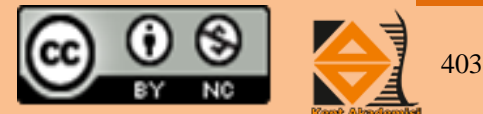




\section{Nk’Mip Çöl Kültür Merkezi (Desert Cultural Centre)}

Kanada'da 2007 yılında yapılan çöl kültür merkezi yaban hayatı koruma ve sosyal hizmetler için kurulmuş bir yapıdır (Şekil 20 a, b). Dialog Mimarlık tarafından çevre dostu bir bina olarak tasarlanmış ve yenilikçi mimarisi açısından ödüller almıştır. Antik bina yapım tekniği olan sıkıştırılmış toprak (Rammed eart) tekniğinin modern teknolojiye uygulanması ile yapılmıştır. Yapının toprak karışımında yerel toprak, mineral pigment ve katkı olarak çimento kullanılmıştır. Toprak harç kalıplara dökülerek ve sıkıştırılarak duvar katmanları oluşturulmuştur. Kalın duvarları ile yapının enerji verimliliğine önem verilmiş aynı zamanda çelik takviye katmanı ile depreme dayanıklılığı arttırılmıştır. Binanın yarısı toprak altında, Okanagan geleneksel kış konutlarının kullanımına benzer özellikte planlanmıştır. Merkezde böceklerden zarar görmüş mavi boyalı ahşap kullanılarak yerel malzeme kullanımına verilen önem gösterilmiştir. Yapının betonarme çatısı üzerine $20 \mathrm{~cm}$ 'lik toprak serilerek çöl bitkileri ekilmiş ve oluşturulan yeşil çatı ile çevredeki çölün devamlılığ sağlanmıştır. Binanın 1sıtılması ve soğutulması için zemin ve tavana yerleştirilen radyant borulardan yararlanılmış klima kullanılmamıştır. Yaz döneminde tavandaki borulara soğuk su verilerek bina serinletilmiş kış döneminde zemindeki borulara sıcak su verilerek yapı 1sıtılmıştır (URL 20).
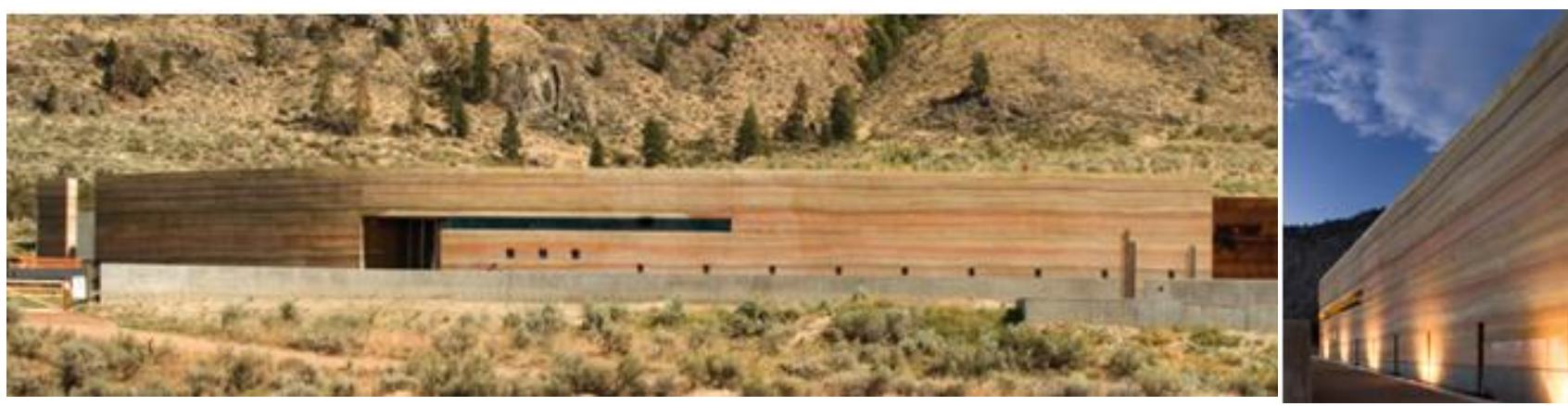

Şekil 20 a. Yapının genel görünümü (URL 21)

b. Duvar dokusu (Nic Lehoux)

Ricola Kräuterzentrum (Ricola herb center - Ricola bitki merkezi)

Mimar Herzog ve De Meuron tarafından tasarlanan yapı 2014 yılında İsviçre'de Laufen'de nane şekeri firmasının tesisi olarak yapılmıştır (Şekil 21 a). Yapı betonarme strüktür üzerine topraktan preslenerek yapılmış toprak bloklar ile inşaa edilmiştir (Şekil 21 b, c). Toprak karışıma kireç ve volkanik tüf eklenmiştir (URL 22).

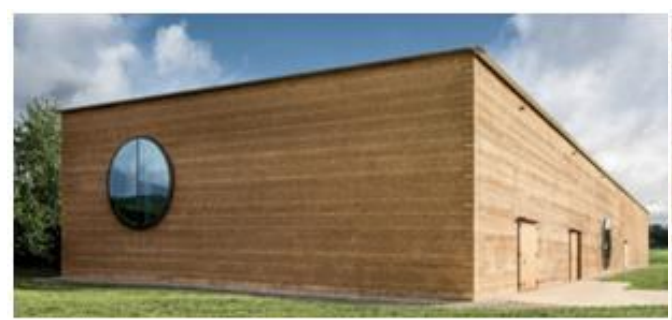

Şekil 21 a. yapının genel görünüşü (URL 22)

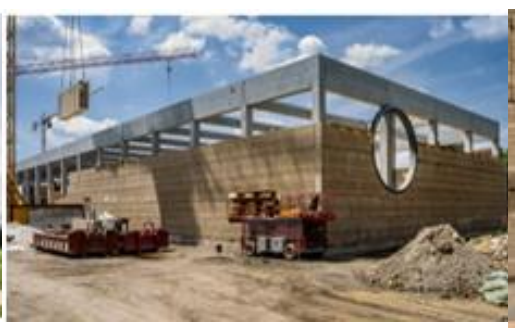

b. Betonarme strüktür (URL 22)

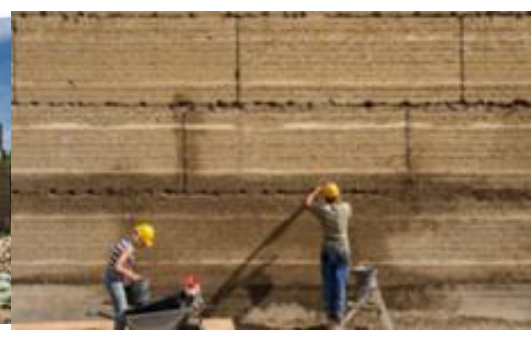

c. duvarda kerpiç blok kullanımı (URL 22)

\section{Arizona'da Konut}

Arizona'da kalıp içine katmanlı olarak sıkıştırılmış toprak kullanılarak yapılmış yapıda yerel toprak renkleriyle çevreye uyumlu bir doku oluşturulmuştur (Şekil $22 \mathrm{a}, \mathrm{b}$ ). Yapıda kullanılan kalın duvarlar doğal yalıtım ve termal 
enerji depolaması sağlamaktadır. Kışın içerdeki sıcak havayı korumakta yazın gündüz güneş 1sısını toplayarak gece ise salınımını sağlamaktadır (URL 23).
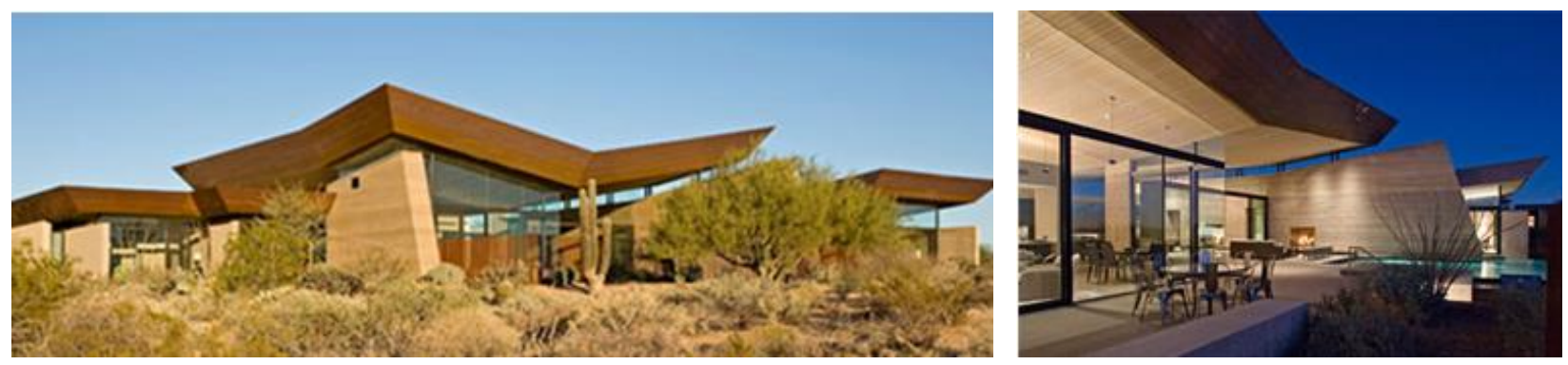

Şekil 22 a, b. Arizona'da kerpiç yapı (URL 23).

\section{Windhover Rehabilitasyon (Contemplative) Merkezi}

Yapı Stanford United States'te, Aidlin Darling Design tarafindan tasarlanmış ve 2014 yılında inşaa edilmiştir. Stanford kampüsünde kişisel yenilenmeyi teşvik eden bir rehabilitasyon merkezidir. Bu merkezin yapılma amacı çalışanların ve öğrencilerin düşünmek, ruhlarını tazelemek yenilenmek gibi eylemleri gerçekleştirebilecekleri sanat peyzaj ve mimari konsept içinde bir ortam yaratmaktır (Şekil $23 \mathrm{a}, \mathrm{b}$ ). Sikıştırılmış topraktan yapılmış duvarlar sergilenen resimler için zemin oluşturmuş ve aynı zamanda termal izolasyon sağlamıştır. Duvarlar için çevreden getirilen toprağın dışında temel kazısından elde edilen toprak da kullanılmıştır (URL 24).

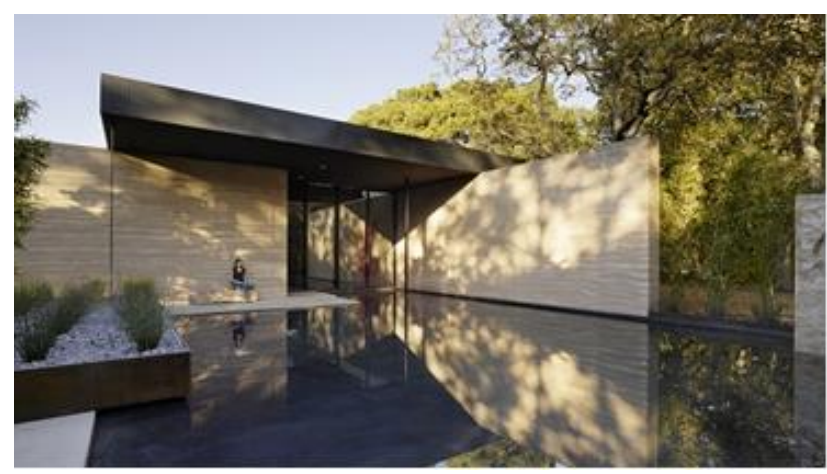

Şekil 23 a. Yapının diş görünümü (URL 25)

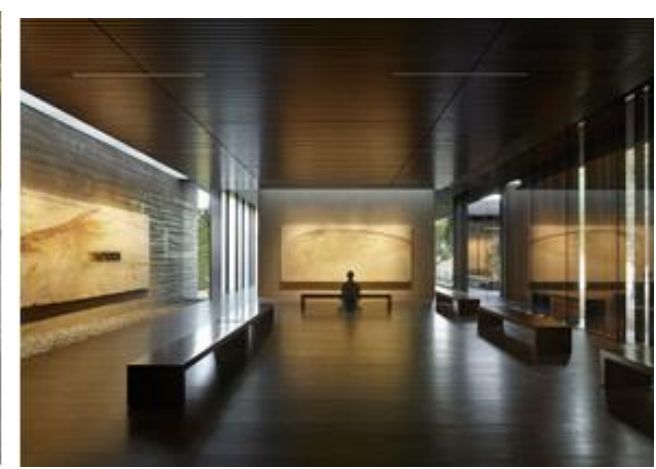

b. İçerden görünüm (URL 25)

\section{Avusturalya'da Layer House}

Robson Rak Architects firması tarafından $470 \mathrm{~m}^{2}$ olarak tasarlanan konut 2016 yılında yapılmıştır. Konutun yapımında yerel malzeme kullanımına önem verilmiş, genel olarak sıkıştırılmış toprak ve ahşap kullanılmıştır (Şekil 24. a, b). Sıkıştırılmış toprak duvarların yapımında toprağın içerisine yine yerel olarak elde edilen kum katılmış ve duvarlar yerel zanaatkarlar tarafından inşaa edilmiştir. Eskimeyen sürdürülebilir ve zarif bir duvar olarak sıkıştırılmış toprak ile birlikte kullanılan kerestenin zaman içinde grileşmesine ve yaşlanmasına izin verilmiş, ahşaplar doğal halleri ile kullanılmıştır (URL 26). 

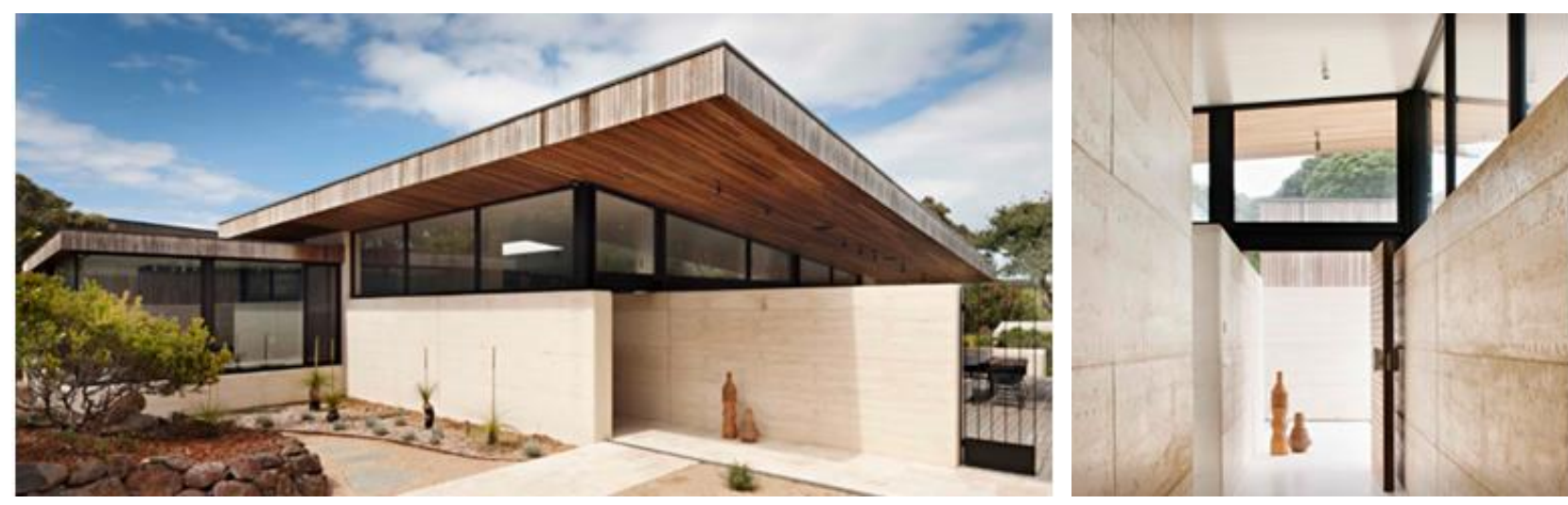

Şekil 24 a. Konutun diş görünüşü (URL 26) b. İçerden görünüş (Shannon
McGrath)

Hem kamu binaları hem özel konutlar için kullanılmış çağdaş kerpiç yapılar için pek çok örnek verilebilir. Burada amaç günümüz çağdaş kerpiç yapı örnekleri hakkında genel bilgi vermektir. Verilen örneklerde çağdaş kerpiç yapım tekniğinin yığma sistem dışında karma sistemlerle entegre olarak kullanılabildiği de görülmektedir.

\section{3. Çevreci Yapılar ve Kerpiç Yapıların Değerlendirilmesi}

Yapıların çevreye genel olarak iki şekilde zarar verdiği belirtilmişti, bunların ilki yapım sürecinde oluşan kirlilik idi. Bunlar; yapı malzemelerinin üretimine, malzemelerin inşaat alanına taşınmasına bağlı faktörler olarak belirlenmiştir. Çalışmada incelenen örneklerin çevreci yaklaşımlar ile üretilmiş örnekler olması nedeniyle tasarımsal nedenlerden kaynaklı sorunlar değerlendirme dışı tutulmuştur. İkinci kirletici ise yapıdaki yaşama sürecinde kullanılan enerji ve konfor koşullarının sağlanmasıdır. Bunlar da genel olarak iklimlendirme ve aydınlatma olarak ele alınmaktadır. Burada aydınlatma parametreleri de tasarım açısından göz önünde tutulmuş olacağı varsayımı ile değerlendirme dışı tutulmuştur.

Belirlenen temel kriterler açısından atık malzemeler ve çevreci yaklaşımlar ile üretilmiş örnekler kerpiç yapılar ile Tablo 1. de karşılaştırılmıştır. Kerpiç yapılar için örnekler aynı malzeme ile yapılmaları nedeniyle tek tek ele alınmamış toprak yapı özellikleri taşımaları nedeniyle tek bir sütunda genel olarak değerlendirilmiştir. Tablodaki verilerin değerlendirilmesinde tek bir yapı inceleme ya da deneysel çalışma içermediğinden ele alınan örneklerde genel kabuller üzerinden değerlendirmeler yapılmıştır. Karşılaştırma tablosu dışında çalışmada verilen kerpiç yapı örneklerine ait çevreci özellikler hakkında da kısa bir değerlendirme yapılmıştır.

Tablo 1. Birinci bölümde çevreci yaklaşımlara ait örnekler ile ikinci bölümdeki kerpiç yapıların çevrecilik açısından karşılaştırılmaları 


\begin{tabular}{|c|c|c|c|c|c|c|c|}
\hline & Örnek yapılar & 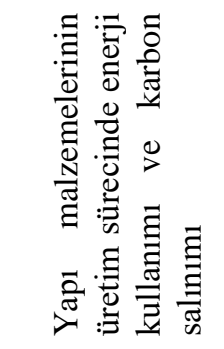 & 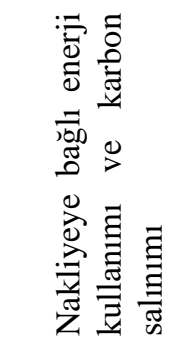 & 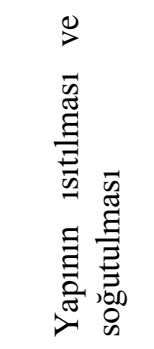 & 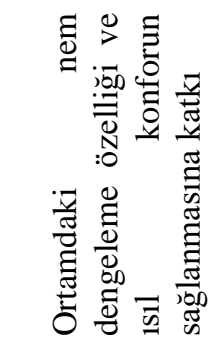 & 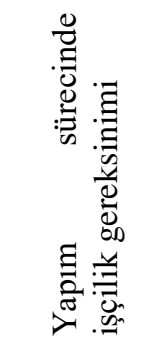 & 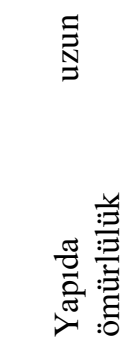 \\
\hline 1 & Mokoko Yüzen Okulu & YOK & MINIMUM & YOK & YOK & VAR & VAR \\
\hline 2 & $\begin{array}{l}\text { Anupama Kundoo - } \\
\text { Yapıda Su Künkleri } \\
\text { kullanımı }\end{array}$ & $\begin{array}{l}\text { YOK (GERİ } \\
\text { DÖNÜŞÜM) }\end{array}$ & MINIMUM & YOK & YOK & VAR & VAR \\
\hline 3 & $\begin{array}{l}\text { Anupama Kundoo - } \\
\text { Yap1da Cam Bardak } \\
\text { Kullanımı }\end{array}$ & $\begin{array}{l}\text { YOK (GERİ } \\
\text { DÖNÜŞÜM) }\end{array}$ & MINIMUM & YOK & YOK & VAR & VAR \\
\hline 4 & $\begin{array}{l}\text { Dönüştürülmüş̧ İnşaat } \\
\text { Attkları Kullanımı }\end{array}$ & $\begin{array}{l}\text { VAR (GERİ } \\
\text { DÖNÜŞÜM) }\end{array}$ & VAR & YOK & YOK & VAR & VAR \\
\hline 5 & Atık Pet Şişe Kullanımı & $\begin{array}{l}\text { KISMEN } \\
\text { VAR }\end{array}$ & MINIMUM & YOK & YOK & VAR & YOK \\
\hline 6 & $\begin{array}{l}\text { Atık Araba Lastiği } \\
\text { Kullanımı }\end{array}$ & $\begin{array}{l}\text { YOK (GERİ } \\
\text { DÖNÜŞÜM) }\end{array}$ & MINIMUM & VAR & VAR & VAR & VAR \\
\hline 7 & $\begin{array}{l}\text { Kağıttan Elde Edilen } \\
\text { Tüplerin Kullanımı }\end{array}$ & VAR & VAR & YOK & $\begin{array}{l}\text { KISMEN } \\
\text { VAR }\end{array}$ & VAR & YOK \\
\hline 8 & $\begin{array}{l}\text { Kenevir } \\
\text { (HempCrete) }\end{array} \quad$ Betonu & VAR & VAR & VAR & VAR & VAR & VAR \\
\hline 9 & $\begin{array}{l}\begin{array}{l}\text { Mantar } \\
\text { (Mycelium) }\end{array} \\
\end{array}$ & YOK & VAR & YOK & YOK & VAR & YOK \\
\hline 10 & $\begin{array}{l}\begin{array}{l}\text { Kereste } \\
\text { (Timbercrete) }\end{array} \\
\end{array}$ & VAR & VAR & $\begin{array}{l}\text { KISMEN } \\
\text { VAR }\end{array}$ & VAR & VAR & VAR \\
\hline 11 & Kerpiç yap1 & YOK & MINIMUM & VAR & VAR & $\begin{array}{l}\text { VAR/ } \\
\text { KISMEN } \\
\text { VAR }\end{array}$ & VAR \\
\hline
\end{tabular}

Tablo 1'e göre çevreci yaklaşımlarla çözülmüş on örnek ve kerpiç karşılaştırıldı̆̆ında;

Yapı malzemelerinin üretim sürecinde enerji kullanımı ve karbon salınımı açısından ele alındığında 2, 3, 6 numaralı örnekler geri dönüşüm malzemesinden elde edilmeleri nedeniyle enerji tüketimi ve karbon salınımına neden olmamaktadırlar. 1 numaralı örnek doğal malzeme olduğundan yine karbon salınımı ve enerji tüketimi bulunmamaktadır. 4 numaralı örnek geri dönüşüm olmasına rağmen yeniden bir üretimin yapılması nedeniyle enerji tüketimi ve karbon salınımı bulunmaktadır. 5 numaralı örnekte atık pet şişeler başka sanayi ürünleri ile birlikte kullanılabilmektedirler bu nedenle kısmen enerji tüketimi ve karbon salınımı söz konusudur. 7,8 ve 10 numaralı örnekler de doğal malzemelerden üretilmelerine karşın bir üretim süreci ve bazı katkıların kullanılması ile enerji ve 
karbon salınımına neden olabilmektedirler. 9 numaralı örnekte doğal malzeme bazı katkılarla kalıplanmaktadır ve karbon salınımına neden olmamaktadır.

Toplamda bu malzemelerin 5 tanesinin üretiminde enerji gereksinimi ve karbon salınımı yoktur. Birinde kısmen var diğerlerinin de karbon salınımı vardır. Neredeyse yarısı bu veriyi sağlayamamakta iken kerpiç yapı üretiminde enerji tüketimi ve karbon salınımı yoktur. Toprağın kalıba doldurulması shotcrete makinesi ile yapılacaksa sadece bu makinenin kullanım süresince elektrik tüketilebilecektir.

Nakliyeye bağlı enerji kullanımı ve karbon salınımı açısından ele alındığında 1,2,3,5 ve 6 numaralı örneklerde malzemeler yakın çevreden elde edinildiklerinden minimum seviyede enerji ve karbon salınımı vardır bunun yanı sıra diğer 4, 7, 8, 9 ve 10 numaralı örneklerde sanayi ürünü olmaları nedeniyle nakliye ve buna bağlı enerji ve karbon salınımı tam olarak vardır. Kerpiç yapıların pek çoğu için yakın çevreden toprak temin edilebilmekte bazı yapılarda temelden çıkarılan toprağın kullanıldığı da görülmektedir. Bu açıdan kerpiç yapılarda ya hiç nakliye gerekmemekte ya da çok az gerekebilmektedir.

Yapının 1sıtılması ve soğutulması açısından ele alındığında 1, 2, 3, 4, 5, 7, 9 numaralı örneklerin 1sı tutucu özellikleri yoktur ve bu malzeme ile üretilmiş yapıların bir kısmı geçici olarak inşaa edildiklerinden ya da iklimsel koşullar nedeniyle ısıtma ve soğutma gereksinimi taşımamaktadırlar. Buna karşın kerpiç malzeme kalın duvar ve toprak malzeme nedeni ile ısıyı koruma özelliğe sahiptir.

Ortamdaki nem dengeleme özelliği ve ısıl konforun sağlanmasına katkı açısından ele alındığında 1, 2, 3, 4, 5, 9 numaralı örneklerde kullanılan malzemelerde nem dengeleme özelliği yoktur. 7. Örnekte kullanılan katkı ile yağmura dayanıklı hale getirilen kağıt doğal halini kaybetmesi nedeniyle kısmen nem dengeleyici olabilmektedir. 6 . ve 10 . Örneklerde biri toprak dolgulu diğeri ahşap içerikli olması nedeniyle nem dengeleyici oldukları söylenebilir. Buradaki örneklere bakıldığında altı yapı ve biri de kısmen nem dengeleyici özellik göstermemektedir buna karşın kerpiç yapılar nem dengeleme özelliği taşımaktadırlar.

Yapım sürecinde işçilik gereksinimi ele alınan örnek yapıların hepsinin inşaası için işçilik gereksinimi vardır. Kerpiç yapılara bakıldığında ise geleneksel sistemle yapılanlarda işçilik gereksinimi varken çağdaş sistemle üretilen kerpiç yapılarda kalıp içine toprağın sıkıştırılması tokmaklanarak yapıldığında minimumdur. Eğer bir shotcrete makinesi ile yapılırsa işçilik süresi ve maliyeti çok çok daha aşağıya inebilmektedir. Bu süreçte duvar örme işlemi tamamen ortadan kaldırılmaktadır.

Tablodaki özellikler açısından bakıldığında kerpiç yapılar tüm olumlu nitelikleri taşırken diğerlerinin pek çoğu tam olarak bu özellikleri karşılayamamaktadırlar.

\section{Örnek olarak verilen kerpiç yapıların tümüne bakıldığında;}

$\mathrm{Bu}$ yapıların çok uzun ömürlü oldukları söylenebilir. Oldukça ekonomiktirler ve 1sı yalıtım gerektirmezler. Uygulama tekniğine uygun yapıldıklarında depreme dayanıklıdırlar. Örneğin İTÜ Ayazağa kampüsündeki yapı ve Anadolu Meleği Kadın Eğitim ve Üretim Merkezi depremde hiçbir hasar görmemiştir. Köyceğiz film platosu olarak yapılan yapı sele maruz kalmış ve hasar görmemiştir. Bu kerpiç yapıların hemen hepsinde çevreye uyumlu renk ve doku oluşturulmuştur. Bu yapılar aynı zamanda nemi dengeleme gibi özellikleri yanında özel çözümlerle (1sıtma soğutma aydınlatma sistemleri gibi) çok az enerji gereksinimi göstermektedirler. 


\section{SONUÇ:}

Günümüzde çevresel sorunların ulaştığı seviye tüm insanları endişelendirecek boyutlara ulaşmıştır. Dolayısı ile tüm sektörler ve elbette inşaat sektörü de daha çevreci yapılar üretme anlamında çalışmalarını sürdürmektedir. Bu yaklaşımlarda yerel malzeme kullanmak, böylece nakliye ve yakıt gereksinimini en aza indirmek, daha ekonomik çözümler üretmek, yapı malzemelerinin üretimi sırasında doğaya zararlı kimyasallar birakmamak, üretilen yapılarda çevreye daha az zarar vermek yani çevreci malzemeler kullanmak ve bu yapıların geri dönüştürülebilir olmalarına önem vermek başlıca yaklaşımlardır. Aynı zamanda yapıların kullanımları sürecinde gerekli enerji de oldukça önemli bir oranda çevre kirliliği oluşturduğundan bu süreçte daha az enerji ile gerekli konforun sağlanması ve daha az çevreye zararlı atık bırakılması konusunda da önlemlerin alınması önem kazanmıştır.

Çalışmanın birinci bölümünde bu bilinç ve yaklaşımla yapılmış örnekler ele alınmıştır. Bu örneklerin bir bölümünde yerel malzemelerle en ekonomik ve çevreye en az zarar veren yapıları üretme çalışmalarına yer verilirken bir bölümünde ise çevrede atık oluşturan malzemelerin geri dönüşüm olarak kullanımını amaçlayan yapılara yer verilmiştir. Bu kapsamda ele alınan yapılara bakıldığında pek çok geri dönüşüm ya da çevreci olarak üretilen yapı malzemelerinin kullanımında yine bir üretim süreci gerektiği, az da olsa doğal kaynakların kullanıldığı görülmektedir. Ya da bu malzemeler, üretilmiş başka malzemeler ile birlikte kullanılabilmektedirler. Bu da söz konusu malzemelerin sanayi ürünü desteği nedeniyle enerji gereksinimi olduğunu göstermektedir. Ayrıca bu yapıların da geri dönüşümü mümkün olmakla birlikte bazıları için yeniden bir işlem gerekebilmektedir. Bu süreç te yine enerji harcamakla mümkün olabilmektedir.

Çalışmanın ikinci bölümünde çağdaş kerpiç yapım tekniklerine ve yapılmış örneklere yer verilmiştir. Bu yapılara çevrecilik ilkeleri açısından bakıldığında sıkıştırılmış toprak yapılardaki toprak kullanımında yapım için gerekli malzeme yapının yakınından hatta temel kazısından elde edilen toprak ile sağlanabilmektedir. Bu toprağın yeterince uygun olmaması halinde bazı katkılar ile iyileştirilerek kullanılması mümkündür. Bu yöntemle duvar yapımında duvar örgüsü için gereken malzemelerin üretimi, taşınması, yerinde örülmesi gibi kalemler ortadan kaldırılmakta ve büyük oranda enerji, iş̧̧ilik, zaman kaybı önlenmekte ve bu süreçte oluşan çevre kirliliği ortadan kaldırılmaktadır. Bu yöntemle oluşturulan duvar yüzeyleri, sıva ve boya gereksinimini ortadan kaldırmakta ve bu sektörün oluşturduğu kirlilik de böylece engellenmektedir. Bu yöntemle üretilen yapının ömrü bittiğinde toprak tekrar geri dönüştürülmekte ve hiçbir atık oluşturmamaktadır.

Çevreci çözüm arayışları ile üretilen yapılar ve kerpiç yapılar karşılaştırıldığında çevreci yapıların bir kısmı kerpiç yapıların avantajlarını sağlarken bir kısmı bu avantajları sağlayamamıştır. Günümüzde gelinen noktada araştırılan doğal ve çevreci malzeme arayışları sürmektedir ve pek çok malzemenin araştırılmasına devam edilmesi kaçınılmazdır. Çevreci malzeme arayışları geri dönüşüm malzemelerinin ve atıkların yok edilmesi açısından da çok önemli ve gerekli bir yaklaşımdır. Ancak bu süreçte de yine atıklardan yeni malzeme üretmek için enerji harcanmakta ve sanayi işin içine girebilmektedir. Yanı sıra malzemenin nakliyesi de enerji tüketimi ve çevre kirliliğine neden olabilmektedir. Bütün bu çevre koruma yaklaşımlı yapılarda da bir miktar enerji gereksinimi ve çevre kirliliğinin olmasına karşın kerpiç yapılar çok daha avantajlı olarak karşımıza çıkmaktadır. Çevreci yapılar kapsamında ele alınan çağdaş sistemle yapılmış kerpiç yapılarda sanayi ürünleri ve taşınması gibi pek çok süreç ortadan kalkmakta ya da minimuma indirilmektedir. Bu nedenlerle kerpiç yapılar çevreci birçok yapıya göre çok daha avantajlıdırlar. $\mathrm{Bu}$ koşullarda atıkların değerlendirilmesinin başka yerlerde (örneğin inşaat atıkları yol ve park agresı şeklinde) çevreye daha az zarar verecek şekillerde değerlendirilme olasılıkları araştırılmalıdır.

Verilen kerpiç yapı örnekleri bu yapım sisteminin çağdaş yapılardan beklenen özellikleri sağlayabildiklerini de göstermektedir. Dolayısı ile bu yapıların çok katlı olmayan yapılar için uygun bir yöntem olarak yaygınlaştırılması ve teşvik edilmesi çevremizi koruma yaklaşımlarında önemli bir tercih olarak öne çıkmaktadır.

\section{Etik Standart ile Uyumluluk}

Çıkar Çatışması: Yazar herhangi bir kişi veya kurumla çıkar çatışmasının olmadığını beyan eder.

Etik Kurul İzni: Bu çalışma için etik kurul iznine gerek yoktur

Finansal Destek: Yoktur.

Materials and Production Techniques in Environmental Approaches; Contemporary Adobe Buildings

Journal of Urban Academy | Volume: 14 Issue: 2 | ISSN: 2146-9229

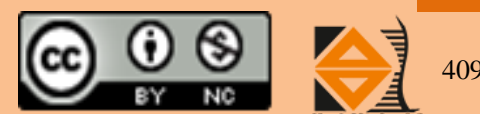




\section{KAYNAKÇA:}

\section{Kitaplar;}

Aycı, H. (2021). Fakir Yapı Kavramı ile Ağa Han Mimarlık Ödülleri/ Arcadia Eğitim Projesi ve Mokoko Yüzen Okulu'nun Değerlendirilmesi, Editör: Murat Dal, Kitap Bölümü-Bölüm: XV, sf:403-425, Mimarlık Bilimleri ve Teknolojisi, ISBN: 978-2-38236-093-4 Livre de Lyon, France

Berge, B. (2009). The Ecology of Building Materials, ISBN 978-1-85617-537-1, Oxford, UK, Elsevier Ltd.

Sayed, M., S. (2020). TÜRKIYE'DEKİ KERPIÇ İNŞAAT GELENEĞİNIN KORUNMASI IÇi̇N SIKIŞTIRILMIŞ TOPRAK BLOK ÜRETIMINDE FARKLI STABILLİZATÖRLERIN KULLANILABİLIRLIGGİ ÜZERINNE BİR

Silver P. ve Mc Lean W., (2013). Introduction to Architectural Technology,2nd edition, Laurence King Publishing, (Çev. Tağmat T. S., Mimarlık Teknolojisine Giriş, YEM Yayın)

ARAŞTIRMA, (Yüksek Lisans Tezi), Fatih Sultan Mehmet Vakıf Üniversitesi Lisansüstü Eğitim Enstitüsü Mimarlik Anabilim Dalı

\section{Bildiriler;}

Akbaş M., (2020, 16 Şubat). Mimaride özümüze geri dönelim, Yeni Şafak Pazar Eki, https://www.yenisafak.com/hayat/mimaride-ozumuze-geri-donelim-3525799

Bektaş, C., (2019). Kerpic 2019 Konferans sunumu, Earthen Heritage New Technology, Management $7^{\text {th }}$ International Conference 5-7 September Köyceğiz, Muğla Turkey

Çavuş, M., Dayı, M., Ulusu, H. ve Aruntaş, Y., (2015). SÜRDÜRÜLEBİLİR BİR YAPI MALZEMESİ OLARAK KERPIÇ. 2nd International Sustainable Buildings Symposium, Gazi Üniversitesi, Ankara, 184-192

Çekirge, G. ve Çubukçuoğlu, B. (2017). İnşaat Sektöründe Sürdürülebilirlik ve Atık Yönetiminin Önemi: Vaka Çalışması Örneğiyle. Uluslararası Katılımlı 7. İnşaat Yönetimi Kongresi, Samsun, sf: 283-289, 11.02.2021 tarihinde https://www.imo.org.tr/resimler/ekutuphane/pdf/18231_26_43.pdf adresinden erişildi.

Işık, B. (2020). Hypothesis on Earthquake Risk Preparedness on in-use Earthen Buildings, 8th International Kerpic Conference: KERPIC'20, November 2020, Istanbul, pg: 29-35

Kaplan, T., (2020), SALT025-CENGİZ BEKTAŞ-002, Cengiz Bektaş ile Mimari Üretimleri Üzerine Bir Söyleşi, SALT Araştırma Mimarlık ve Tasarım Arşivi, https://saltonline.org/media/files/cengiz_bektas_010620_scrd.pdf

Kundoo A., 2017 yıl1 40. Yap1 Fuarı sunumu, 'THINKING WITH THE HANDS' 23-27 Mayıs Turkey Build TÜYAP Fuar ve Kongre Merkezi Büyükçekmece İstanbul/Türkiye

Sezer, S. N. ve Arpacioğlu, Ü., (2020). A Study On The Suitability Of Green Facade Applications With Kerpic Building, $8^{\text {th }}$ International Kerpic Conference: KERPIC'20, İstanbul pg:325-330

Utkutuğ, G. (2011). Sürdürülebilir Bir Geleceğe Doğru Mimarlık ve Yüksek Performanslı Yeşil Bina Örnekleri. X. Ulusal Tesisat Mühendisliği Kongresi, Bina Fiziği Sempozyumu, İZMiR, 1517-1538

Yardımlı S., Dal M., (2016). Water Deterioration in Adobe Structures and Measures to Take, Kerpic'16 Cultural Landscape: Rebuilding after Decay International Conference, İstanbul Aydın University, pg: 112-122

Yardımlı, S., Işık,A. B., Arslan, K., ve Samurkaş, M. (2017). Enzyme and Polymer Contributions and Improvements in Adobe Materials, EARTH USA 20179th International Earthbuilding Conference, Santa Fe, New Mexico, ISBN:

978-1-387-26046-1, 256-267 
Yardımlı, S., Işık, A. B., ve Balık, Ö., (2018). Recommendations for Çanakkale-Ayvacık Post-Earthquake Housing Needs and Solutions, Kerpic'18 - Back to Earthen Architecture: Industrialized, Injected, Rammed, Stabilized, 6th International Conference, Hasan Kalyoncu University, Turkey, 1-2, 43-50

\section{Makaleler;}

Acun Özgünler, S., ve Gürdal, E. (2012), Dünden Bugüne Toprak Yapı Malzemesi: Kerpiç, Restorasyon ve Konservasyon Çalışmaları Dergisi, 9, 29 - 37

Arslan, F. (2014). Türkiye'de Sürdürülebilir Doğal Kaynak Kullanımı Arayışlarına Bir Örnek: Yeşil Binalar. Asos Journal, Akademik Sosyal Araştırmalar Dergisi, 2(2/1), 288-304.

Bhattacharya, S., Nayak, S. ve Chandra Dutta S., (2014), A critical review of retrofitting methods for unreinforced masonry structures, Elsevier International Journal of Disaster Risk Reduction, Volume 7, March 2014, Pages 51-67

Bilgiç, B. (2016). Makoko Yüzen Okulu, ARKİTERA, 11.02.2021 tarihinde https://www.arkitera.com/proje/makokoyuzen-okulu/ adresinden erişildi

Binici H., Durgun, M.Y., ve Yardım Y. (2010). Kerpiç Yapılar Depreme Dayanıksız Mıdır? Avantajları ve Dezavantajları Nelerdir?, KSÜ Mühendislik Bilimleri Dergisi 13 (2).

Güner, A.F., Benli, G. ve Karaçar, P., (2019), Büyükkonuk Eko Festival Alanı ve Çevre Düzenleme Projesi Örneğinde Mimarlık Eğitiminde Mesleki Pratiğin Önemi, Social Sciences ISSN: 1308-7444 (NWSAENS), 3C0184; 14(3):62-76

Işık B. (2011). Conformity of Gypsum Stabilized Earth- Alker Construction with 'Disaster Code 97' in Turkey, Cyprus International University, $\mathrm{N}$-Cyprus , International Journal of Civil \& Environmental Engineering IJCEEIJENS Vol: 11 No:02, April

O’Grady, C.R., Luke, C., Mokrišová, J. ve Roosevelt, C. H., (2018). Interdisciplinary approaches to understanding and preserving mudbrick architecture in regional and diachronic contexts, Cogent Arts \& Humanities, 5: 1553326, https://doi.org/10.1080/23311983.2018.1553326

Perker, Z.S. ve Akkuş, K. (2019). Toprakyapı Malzemesi ile Mimarlık: Çağdaş Uygulamalar Üzerine Bir Değerlendirme, Online Journal of Art and Design, volume 7, issue 4, 160-172

Yardımlı, S., Shahriary A., Güleç Özer D., (2018). Sürdürülebilir Yapı Örneği Olarak Yazd'da Konut Analizi, Online Journal of Art and Design, volume 6, issue 5 (Special issue), 39-53

Tandoğan, O. (2018). Atık Malzemelerinin Mimaride Kullanımı. Ulusal Çevre Bilimleri Araştırma Dergisi, 1(4), 189202

Türküresin, İ. (2017). Toprak, Alker ve Sürdürülebilir Yapılar, Ruhi Kafesçiolu röportajı, EKOIQ, 05.03.2021 tarihinde https://ekoiq.com/2017/04/26/toprak-alker-surdurulebilir-yapilar/ adresinden erişildi

\section{Web siteleri;}

URL 1: 20.02.2021 tarihinde https://earthstructuresafrica.com/rammed-earth/ adresinden erişildi

URL-2: 11.02.2021 tarihinde https://xxi.com.tr/i/cevrenin-ogretileri adresinden erişildi

URL 3: 13.02.2021 tarihinde https://www.stonecycling.com/ adresinden erişildi 
URL 4: 13.02.2021 tarihinde https://loosfm.wordpress.com/homepage/p-e-t-pavilion/ adresinden erişildi

URL 5: 13.02.2021 tarihinde https://simple.wikipedia.org/wiki/Earthship adresinden erişildi

URL 6: 04.03.2021 tarihinde https://en.wikipedia.org/wiki/Shigeru_Ban adresinden erişildi

URL7: $\quad$ 04.03.2021 tarihinde https://www.mimarizm.com/haberler/gundem/shigeru-ban-tasarimi-afet-barinaklarisergisi_128116 adresinden erişildi

URL 8: $\quad 04.11 .2021$ tarihinde https://inhabitat.com/11-green-building-materials-that-are-way-better-thanconcrete/tony-budden-hemp-house-ne-2/ adresinden erişildi

URL 9: 08.03.2021 tarihinde https://inhabitat.com/hemcrete-carbon-negative-hemp-walls-7x-stronger-thanconcrete/hemcrete-6/ adresinden erişildi

URL 10: 08.03.2021 tarihinde https://www.archdaily.com/521266/hy-fi-the-organic-mushroom-brick-tower-opensat-moma-s-ps1-courtyard?ad_medium=widget\&ad_name=recommendation adresinden erişildi

URL 11: 08.03.2021 tarihinde $\quad$ https://inhabitat.com/11-green-building-materials-that-are-way-better-thanconcrete/mushroom-tower-queens-wind-turbines1/ adresinden erişildi

URL 12: 08.03.2021 tarihinde

https://www.certifiedenergy.com.au/emerging-materials/emerging-materialsmycelium-brick adresinden erişildi

URL 13: 08.03.2021 tarihinde https://www.yesilodak.com/betona-alternatif-8-yesil-yapi-malzemesi adresinden erişildi

URL 14: 11.03.2021 tarihinde https://web.itu.edu.tr/ isikb/alker03doc_01.html adresinden erişildi

URL 15: 20.02.2021 tarihinde https://ekoiq.com/2017/04/26/toprak-alker-surdurulebilir-yapilar adresinden erişildi

URL 16: 02.02.2021 tarihinde https://www.kulturportali.gov.tr/portal/catalhoyukneolitikkenti adresinden erişildi

URL 17: 20.02.2021 tarihinde https://van.ktb.gov.tr/TR-76401/van-kalesi.html adresinden erişildi

URL 18: https://kreatifmimarlik.com/project/gobeklitepe-ziyaretci-ve-canlandirma-merkezi/ adresinden erişildi

URL 19: 06.06.2021 tarihinde https://www.yenisafak.com/hayat/mimaride-ozumuze-geri-donelim-3525799 adresinden erişildi

URL 20: https://nkmipdesert.com/our-sustainable-building/ adresinden erişildi

URL 21: https://www.archdaily.com/508294/nk-mip-desert-cultural-centre-dialog/537ab7fec07a80946d000047-nkmip-desert-cultural-centre-dialog-photo?next_project=no adresinden erişildi

URL 22: https://openscholarship.wustl.edu/cgi/viewcontent.cgi?article=1351\&context=bcs adresinden erişildi

URL 23: 13.02.2021 tarihinde https://dornob.com/rammed-earth-house-brown-red-brilliant-green-design/ adresinden erişildi

URL 24: 11.03.2021 tarihinde https://www.enr.com/articles/38048-culturalworship-best-project-stanford-windhovercontemplative-center adresinden erişildi

URL 25: 13.03.2021 tarihinde https://www.arcadata.com/en/exclu/windhover-contemplative-center-stanford-16.html adresinden erişildi 
URL 26: 13.03.2021 tarihinde https://www.archdaily.com/871521/layer-house-robson-rak-architects-and-interiordesigners/591c3b7ae58ece3a2500017c-layer-house-robson-rak-architects-and-interior-designersphoto?next_project=no adresinden erişildi 